
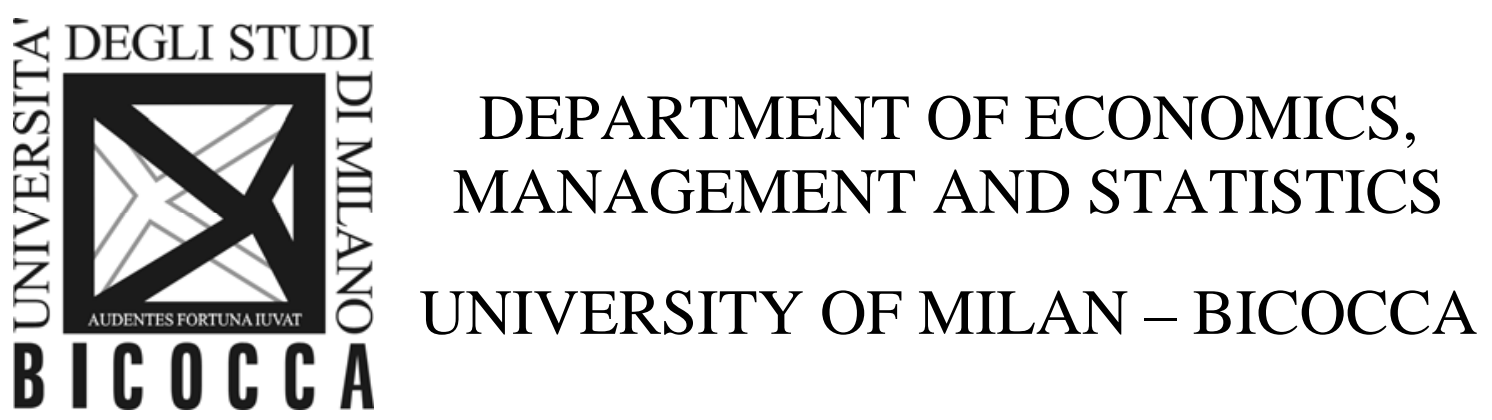

DEMS WORKING PAPER SERIES

Joint-stock companies dynamics, legal institutions and regional economic disparities in Italy (1858-1914)

Pierangelo Toninelli, Claudio Pavese

No. 282 - October 2014

Dipartimento di Economia, Metodi Quantitativi e Strategie di Impresa Università degli Studi di Milano - Bicocca

http://dems.unimib.it/ 


\author{
Pierangelo Toninelli - Claudio Pavese) \\ (University of Milano-Bicocca) \\ Corresponding address: pierangelo.toninelli@unimib.it
}

\title{
Joint-stock companies dynamics, legal institutions and regional economic disparities in Italy (1858-1914).
}

\begin{abstract}
The paper represents the outcome of an ongoing research program on the dynamics of joint stock companies in Italy between the 1861 Unification of the country and World War 1. It is based on a considerable quantity of data, the bulk of which is constituted by the very detailed set covering the 18831913 period, which started to be collected many years ago and has a very reliable empirical support, the weekly companies' official bulletin. Furthermore evidence for the preceding years have requested accurate investigation about the disposable quantitative information, their homogeneity and comparability. Apart from commenting upon the result of this unique collection of quantitative information, the paper will hopefully provide a not negligible contribution to the explanation of the Italian first period of economic growth and - more specifically - to the origins and evolution of the country's regional inequalities. It is aimed at enlightening internal economic and social disparities also in terms of the diverging rhythm of private capital formation between the northern and southern regions. It will inquire if and how the jointstock companies long-term dynamics showed unequal regional concentration, therefore penalizing the economic growth of the areas less affected by the phenomenon.
\end{abstract}

JEL classification: N230, N130, K220

Keywords: Italy pre-1913, joint stock companies, corporate law

\footnotetext{
* The authors like to thank also Franco Amatori, Andrea Colli, Renato Giannetti, Ioanna Pepelaisis, Giandomenico Piluso and Michelangelo Vasta, for their helpful comments: of course the usual disclaimer applies. The research has been partly supported by the FAR funds provided by the Bicocca University in Milan.
} 


\section{Joint-stock companies dynamics, legal institutions and regional economic disparities in Italy}

(1858-1914).

\section{Introduction.}

The long-standing debate on Italian dualism has been explaining the Southern economic gap vis-àvis the rest of the country and especially the North in terms of pre-existing backwardness, different endowment of fixed and/or mobile resources, low social capital, poor economic institutions, discriminating central policy and so on. On the contrary entrepreneurship and private capital formation have been so far rather neglected. Yet this looks quite a promising approach, which can be pursued using as a proxy information concerning the dynamics of Italian joint stock companies as well as società anonime (S.A), that is the particular type of company characterizing most of the civil law countries and roughly corresponding to the UK limited companies.

The following paper will hopefully provide a not negligible contribution to the explanation of the Italian first period of economic growth and - more specifically - to the origins and evolution of the country's regional disparities. It is aimed at explaining internal economic and social inequalities also in terms of the diverging rhythm of private capital formation between the northern and southern regions. Such a difference was likely to be aggravated by the particular post 1894 mechanism of financing joint stock companies by the main banks which had as a consequence that the capital raised by the companies on the private equity market approximated the total industrial investment of the period. It will inquire if and how the joint-stock companies long-term dynamics showed unequal regional concentration, therefore hindering the economic growth of the areas less affected by the phenomenon.

The paper represents a by-product of an ongoing research program on the dynamics of joint stock companies in Italy between the 1861 Unification of the country and World War 1. It is based on a massive quantity of data, the bulk of which is constituted by the data -set covering the 1883-1913 period, which started to be collected many years ago and has a very reliable empirical support, and which soon will be made available to the researcher. The preceding years have requested accurate investigation about the disposable quantitative information: more precisely about the very existence of relevant data, their homogeneity and comparability. 
The paper is organized in the following way: in the first section the issue will be briefly discussed, section 2 will be devoted to the presentation of the data set and of the sources of the research, in paragraphs 3 and 4 the evidence concerning respectively the 1858-1882 and the 1883-1913 periods will be offered, while a conclusive paragraph will round out the paper.

\section{The issue}

Since the creation of the Kingdom of Italy (1861), the so called "questione meridionale" appeared as the most critical issue of the modern history of the country, even though perhaps not with the extreme meaning expressed by Giuseppe Mazzini, that is "Italy will be what the South of Italy will be". As a matter of fact the dualism between North and South, i.e. the diverging trends of growth of the two Italy, has been blamed as the heaviest failure of the Risorgimento: good intentions did correspond at times to the understanding of the gravity of the issue but, rarely, adequate politics did. Yet when this happened not negligible results have been reached, such as during the golden age (1951-1971), when the previously diverging trend of the per capita income was inverted.

What appears still uncertain even today is the evaluation of the North-South differential in the first fifty years of the new nation: was it there already in 1861 ? If so, when and how did it increase? If not, when did it appear? The controversy is not at all secondary, as it fits logically the argument which blames the Unification of the peninsula for the economic inferiority of the South, until recently quite a fashionable position. Already in 1900 Francesco Saverio Nitti, an outstanding protagonist of the economic and political life of the young country wrote that the national integration had been made by sacrificing the Southern regions: in so doing he was ambiguously providing an optimistic evaluation of their economic starting conditions, even though he didn't spare severe considerations about the cultural, institutional and economic misery of the Bourbon Kingdom and especially on its worst plague, corruption [Nitti 1900]. Yet it is especially since the 1960s that a strongly revisionist position took momentum: it goes from the strong accentuation of the sacrifice induced by the protectionist tariff, which penalized the promising beginning of an industrialization process in the former Bourbon territories, to the recent intellectual provocative suggestion "of abolishing the Mezzogiorno" (Viesti 2003).

Today the debate has assumed a strong quantitative inclination as an increasing number of GNP series has been produced in the last decades - the "Italian GNP manufacture" as it has been 
labeled - which show negligible differences for the first post-unification decades, somehow disorienting the scholar. Thus, for instance, extrapolating Federico 's (2007) and Fenoaltea's (2003) regional estimates for agriculture and industry, and Felice's estimates for services in 1891 (Felice 2005) Daniele e Malanima (2007 and 2010) maintain that there was practically no economic gap between North and South at the time of Unification: divergence was chiefly the outcome of the post 1890s government policy. On the other hand, this finding contrasts with previous estimates, as well as with the most traditional wisdom which tends to regard regional inequalities as rooted in the Italian past ${ }^{1}$. Looking for instance at the density of the industrial workers in the different Italian regions in 1878 , values such as $0.35 \%$ of the regional population (Calabria), 0.24\% (Sicily) and 0,01\% (Sardinia) compare with much bigger figures (however low by the standard of the most advanced countries) of northern and central regions: $4,2 \%$ of Lombardy and $2,2 \%$ of Piedmont as well as with a national average of $1,4 \%$ (Ellena 1878$)^{2}$. Ultimately the most recent estimate by Brunetti, Felice \& Vecchi (2011) attributes a 16\% advantage to the North, which gets even sharper if disaggregated into macro-regional details: $25 \%$ in 1871 between the North-western regions and the Mezzogiorno. Other indicators usually advanced to explain contemporary backwardness of countries (according to modern synthesis of theory of economic growth, f.i. Galor 2011) such as literacy, life expectancy, children mortality, height, all point to the same direction, i.e. the North vs. South advantage already in existence in the new country's infantry; besides, a different attitude toward innovation distinguished between an active modernization of northern and central regions and the passive one of the southern (Felice-Vasta 2012).

All in all the assumption that on the eve of the union the Italian regions - and, more specifically, North and South - shared similar levels of growth gives support to the hypothesis that they were also characterized by analogous "external conditions", such as, for instance, institutions,

\footnotetext{
${ }^{1}$ For a recent thorough discussions see Felice (2007, 2014), Perrotta- Sunna (2012). Besides, a rich stream of studies has traced the origins of Southern underdevelopment back to the medieval age (for a synthesis see Perrotta 2012).

${ }^{2}$ These old observations roughly converge with the recent estimates by Fenoaltea (2003) and Ciccarelli \& Fenoaltea (2010): in particular, according to the latter contribution (tab.3) in 1871 Piedmont, Liguria and Lombardy -i.e. the three most developed regions - showed a density of industrial workforce (on total population) of 1,16 as against 0,89 of the Southern regions.
} 
geography, culture, infrastructure, propensity to trade: a hypothesis which appears most improbable in the light of the contemporary remarks ${ }^{3}$, social commentaries and historical analysis.

In the following we will dwell on one specific aspect, i.e. private capital formation and the dynamics of limited companies. This topic has long been quite neglected, but for a few exceptions, in growth discussing not only by the Italian economic and business historiography: yet the issue has recently been enjoying growing attention even though are still really few the cases of studies fully centered on its quantitative dimension and they deal mostly with joint stock companies births (Freedeman 1979; Harris 2000; Sylla 2002; Wright 2011; Hannah 2013; Sylla \& Wright 2011 and 2013; Pepelasis -Emmanouilidi 2013). Besides, in the Italian case, the Giannetti-Vasta's fundamental contribution, where the accent is primarily on the microeconomic aspects, particularly under the influence of industrial economics, appears very much imbued of Chandlerian suggestions: top ranking, longevity, performance, sectorial and technological distribution and so on.

Conversely the aspect we want to consider here is principally macroeconomic, even though not negligible considerations can be peeped also at the micro level. It builds on the consideration that the limited liability and the multiplication of joint stock companies had a major role in the financial revolution of the XIX century and this profoundly impacted on the modern economic growth of the western world (see f. i. Sombart 1925; Schumpeter 1942; Kuznets 1966; Hannah 1983; Landes 1978 and 2002; Baskin and Miranti 1997). Does this proposition make sense even in a backward country like Italy? Does that dynamics contribute to the explanation of the pattern of growth of the country and, more specifically, to the deepening of the economic differential between North and South?

Yet it has to be remembered that the 1861 making of the Italian Kingdom enormously influenced the history of the country and not only from an economic point of view: the institutional and legislative contexts in the various pre-unification states were even more important. In the SA specific case we are dealing with different ruling procedures - even though sharing the common civil law origins - and/or different political regimes. In fact if the 1807 Napoleonic Code de Commerce was extended to all the territories of the peninsula conquered by the emperor, after his defeat many restored regimes repelled it. Therefore since the $1840 \mathrm{~s}$ in more liberal

\footnotetext{
${ }^{3}$ Such as f.i. William Gladstone's definition of the South: "the negation of God erected into a system of government" (cit. in Felice 2014)
} 
governments - such as the ones of the Grand Duchy of Tuscany or the Sardinia Kingdom - SAs burgeoned whilst in more conservative centralized system like the Kingdom of LombardyVenetia and the Kingdom of the Two Sicilies such a process was greatly slowed down (Acerbi 2011).

\section{The sources and the dataset}

As detailed below and shown in tab A10. the reconstruction of the dynamics of the Italian companies in the fifty-five preceding years has allowed us to fix their number in 1913 at 3773, a figure quite different from the one of 3069 usually referred to ${ }^{4}$.

The collection of quantitative information concerning Italian companies has a twofold origin and is based on different sources. The massive, most important part of it is the set of data concerning Italian companies over the period 1883-1914. It covers the totality of Italian companies, thanks to the capillary scrutiny of the bulky Bollettino Ufficiale delle Società per Azioni, that is the official weekly bulletin reporting all the capital changes within the Italian universe of limited companies. Since 1883 , the year of the new Italian company law, this bulletin had been required by law to register all the companies' births as well as statutory changes such as incorporations, capital variations and closedowns: this means that thousands of relevant pieces of information were recorded each year. Yet not always such mass of information was immediately registered, and occasionally, for different reason -firstly because of the impressive and increasing flow - it could take even years before registration really occurred (nor it can be excluded that some might not have registered at all). Such data have been organized according to different criteria: by main sectors (18) (and further each of them in a number of subsectors), by geographical headquarters and by juridical form.

To overcome possible gaps, the data collected in such a way have been checked and implemented with pieces of information detected in a plethora of coeval economic and financial sources, such as specialized publications, periodicals, semi-public repertories ${ }^{5}$ as well as, since 1907 , a further

\footnotetext{
${ }^{4}$ See f. i. Giannetti - Vasta 2006, Hannah 2013. Such a figure is the one presented in Assonime 1928, whose limits are indicated below in the text.

${ }^{5}$ Such as for instance La gazzetta dei prestiti, II monitore dei prestiti, II sole, Annuario italiano del capitalista, Rivista sulle società commerciali as well as the Piccinelli's repeertoire (1902)
} 
source specifically devoted to the limited companies' demography, published every two or three years: the latter - Notizie statistiche sulle principali società italiane per azioni, edited by the Credito Italiano bank (Credito Italiano, vv years)- registered the financial activities of the companies with a nominal capital greater than 1.000.000 Liras (500.000 in 1914). However, a good testing ground of our dataset is represented by its 1928 issue, by then edited by Assonime (the Association among Italian joint stock companies) which offers a valuable introduction containing post 1872 yearly synthetic data concerning companies' births, deaths, nominal capital variations and bonds, aggregated in 26 sectorial classes.

For what concern the three preceding decades we have to turn to other sources in order to figure out the data for three benchmark years, i.e. the ones for which we have at disposal reliable disaggregate data: first two official publications, covering the period $1858-1865$, both by the Ministero of Agricoltura, industria e commercio (herafter MAIC). The first (MAIC 1865) is supposed to gather all the pre-1865 companies' changes, starting from the maiden registration in the country territories, which occurred in Genoa in $1809^{6}$. According to this source between that year and 1865 the demography of Italian companies listed 570 births and 195 deaths, with a net balance of 370 . However these figures are not completely reliable and can serve just as supporting evidence: for instance the one concerning births is probably underestimated as a few short-lived companies, as well as those closed down long before, were not listed. The second publication (MAIC 1866) was finalized precisely to emendate the previous series, even though, unfortunately, only for the period 1858-1865. The corrections were made on the basis of the observations made by the various Chambers of Commerce, which had been expressly invited to check the information concerning their specific province [MAIC, 1866, p. V]. According to this second source the net balance at the end of 1865 was 343, therefore a bit smaller than the one mentioned above. In any case by crossing the data coming from those two publications, several series have been built which synthesize the quantitative information concerning number and capital changes of the companies over the period 1858-1865: these are split into four macrosectors as well as distributed on a regional basis.

The next year for which we dispose of data disaggregated at the regional level is 1876 , thanks to a rare and precious publication by the same Minister (MAIC 1877). Such a study presents also synthetic, aggregate series of the country for the all the years 1866-1875 (but 1868), organized in

\footnotetext{
${ }^{6}$ It was a branch of the French 'Compagnie anonyme des messageries imperials'.
} 
broad categories and comprehensive as well of popular banks, cooperatives and foreign companies, which anyhow prove quite useful in order to figure out the general trend of the companies dynamics.

Similar aggregate data have been collected from another MAIC serial publication which should in theory continue into the new century, but only two issues of the series seem to have survived, covering the period 1865-1881 (MAIC, 1879 and 1882). As explicitly admitted in the explicative notes of such publications, slight differences have occurred between the first one (MAIC 1877) and the following two (MAIC 1879 and 1882).

It has to be said that unfortunately, as we will better see below, the post 1872 series as produced by the two mentioned sources - MAIC and Assonime - do not overlap even though their trends do convincingly converge. Besides, whilst the Assonime as well as the BUSA 1883-1913 series supplies yearly births, from the 1859-1881 MAIC series we can derive only yearly net balances that is the difference between births and deaths (and mergers and acquisitions) -by subtracting each year's value from the one of the preceding year. Therefore up to 1883 our analysis of company dynamics will be based on yearly stocks and gross flows.

\section{The 1858-1882 period}

In 1858, on the eve of the unification of the greatest part of the peninsula, the number of active companies on the territory next to be included in the Kingdom of Italy was 151, with an aggregate nominal capital of 329,6 million liras. Their distribution was already quite uneven: the northern region, which did not encompass the north-eastern area yet (roughly the Veneto provinces, annexed after the 1866 war), took up $63,6 \%$ of the total (96 companies), the central $22 \%(33)$ and the southern just $14,6 \%$ (22) (see tab.1).

\section{[Insert Table 1 about here]}

The picture improves for the central region if capital is considered, because of the economic relevance at the time of Tuscany, and particularly of Florence, bound to become in a few years the new (temporary) capital of the country: namely the relative shares in this cases become $52 \%$ (North), 41\% (Central) and only $7 \%$ for the South. As a matter of fact the great part of those 
companies was localized in Piedmont, Liguria and Tuscany - which together summed about two third of the total number and $3 / 4$ of overall capital.

Conversely in the South both the number and the invested capital, clearly in unfavorable terms with the two other macro-regions, concentrated in Campania, namely in the Naples area. The latter (with 21 entries) was the fifth region with regard to number - after Piedmont, Tuscany, Lombardy and Liguria - and the fourth for capital, preceding Lombardy.

Even though more than half of the Campania values were to be attributed to maritime insurance companies - a characteristic largely shared with Liguria, as Naples and Genoa were the two main ports of peninsula - the two rankings do not change once the insurance values are removed.

However this was not a clear indicator of backwardness, as a similar situation with regard to the amount of the invested capital was shared by one of the richest areas of the country, Lombardy and particularly by the Milanese region. Possibly this was, as said, the consequence of different legislative and institutional contexts: in particular an irreparable rift between the Austrian government and the people had developed after the 1848 "five days" riots which ended in a severe repression policy whose consequences were felt also in the commercial law as a very tight imperial patent was imposed in December 1852 which transferred the issuing jurisdiction from Milan, the capital of the Kingdom of Lombardy-Venetia, to imperial Vienna. However the hostility toward the constitution of SA had emerged much earlier, as testified by a 1822 pronouncement of the Milanese Chamber of Commerce which considered them "too dangerous" (Tremelloni 1947,6) while in 1837 Carlo Cattaneo, a famous intellectual and politician ironically complained upon the failed attempt to create in the city a "Monte Sete", that is a public company for financing the flourishing silk industry (Cattaneo 1837).

\section{[Insert Table 2 about here]}

A clear improvement was registered after the Piedmont civil law was extended to the entire country: in 1865 the total number of SAs had increased, as said, to 343, with a pace of growth which clearly accelerated after 1862 (see tab.2). In that year also Milan and Naples had become important centers of corporate headquarters: Lombardy in particular, together with Tuscany, emerged as the second region in Italy as for number of initiatives, even though with regard to capital still lagged much behind Tuscany and Piedmont, the regions where most of the capitalintensive companies (banks and railways) were located, and where, before moving to Rome, the 
capital, Turin and Florence in quick succession, had been based (tab.3). This contributed of course to enhancing the value of the nominal capital of the two macro-areas, therefore penalizing as for the overall capital the South (whose share dropped to 3\%).

\section{[Insert Table 3 about here]}

Turning to the manufacturing sector (without railways) in 1865 it involved 204 companies, with a total capital of about 483millions Liras (se tab.4). Lombardy already stand out with regard to the number of manufacturing companies (57), if not for capital: this sounds as a confirmation, first, of the progressive diffusion of an industrial spread particularly throughout its territory, as maintained already many years ago by Luciano Cafagna (1989), and, second, of its future destiny of manufactory engine of the country.

\section{[Insert Table 4 about here]}

Apart from Campania, the data confirm also the enduring backwardness of the southern regions which - together - added up $11 \%$ of the total number of manufacturing companies and $13,3 \%$ of total capital. Yet it can be seen that in a few years (1858-1865) some slight improvement in both the number and the capital value shares had been realized. All in all, therefore, the picture which comes out from the data relative to the joint stock companies dynamics in the years immediately preceding and following the formation of the Italian Kingdom seems to confirm the hypothesis of an already existing differential between the North-Centre and the South. On the contrary the Unification brought about some improvement, particularly in Sicily, where six companies (but mostly insurance) were created, as well as in Campania which almost doubled number and capital, improving mostly in the manufacturing sector. Certainly the image is not homogenous also with regard to the two macro-areas: in particular - as it has been already highlighted by the recent historiography, starting from the 2003 Fenoaltea innovative contribution - the North/South differential seems to go hand in hand with a West-East differential as most Adriatic and Ionian regions shared throughout the period absolute lack of initiatives.

Between 1866 and 1870 the boundaries of the country were affected by major changes as they came to encompass also the north-eastern region and Lazio with Rome, the new capital. This of course influenced the data of the following period. The first year - 1866 - was a critical one in the Italian history because of the Third War of Independence which brought along the nonconvertibility of the currency: this had a depressive effect on the economy and on the JSC 
dynamics which offset the possible propulsive effect of the 1866 issue of the first nation-wide Commercial Code - essentially an extension to the entire country of the slightly amended Piedmont's Commercial Law - as a separate body from the Civil Law. Unfortunately - as said - for the years 1866-1875 we have only aggregate data at the national level, therefore the discussion on the JSC regional distribution has to be deferred to 1876. Yet the general trend takes shape quite clearly: after the pronounced drop of 1866 , when the overall number decreased to 243 , with a remarkable plunge also in the industrial sector, a slow recovery was registered. Then a real (short-lived) boom followed, favored by the international positive conjuncture: in 1873 the total number had jumped to 719 (including 41 foreign companies), mostly prompted by a sort of a bank fever. This was likely to have stimulated new initiatives also in the industrial sector, which registered in that year 323 initiatives, plus 19 railways companies (MAIC 1877, pp. XXXVII-XXXVIII). The trend stabilized for a few years around those values, before registering a new inversion in 1876, precisely the year for which we dispose of a new cross section of the regional distribution of companies.

In that year, characterized by a major reversal of political leadership which saw the Left coalition displacing the Right and taking over the government, the overall number of companies dropped to 643 , a value as always comprehensive also of private companies having a juridical form different from that of SA, such as popular banks and cooperatives (see tab.5). The regional allocation by macro-areas did not significantly change as for the number of companies, whilst the South improved its position with regard to capital, as shown by tab. 6 .

\section{[Insert here Table 5 and 6]}

Besides, from these figures it is possible to grasp the trends concerning number and amount of the capital invested in the preceding 18 years, a dynamics which confirms the general considerations hitherto advanced with regard both to the difficult time experienced by the Italian economy in the period of the forced circulation (1866-1883) and, basically, the enduring gap between the northern-central regions and the South. The 1876 data are detailed by region in tab.7: here the $b$ column of $\mathrm{K}$ is referred to the paid up capital in 1876, a figure which unfortunately is missing for the other benchmark years. The very high values of the central region had to be ascribed to the concentration in Rome and Florence of the main issuing banks and railways companies, as it had previously happened with Turin. Once depurated by these values the resulting picture appear much more explicative. In 1876 the number of industrial and mining 
companies plus railways operating in Italy was 300, therefore quite inferior to the highest value registered, as seen, in 1873.

\section{[Insert Table 7 about here]}

Their number and capital were distributed in the three country's macro-areas as highlighted by table 8 , which once more show a clear superiority of the Northern region, which took a share of $62 \%$ of the number of companies and $61 \%$ of paid up capital (only slightly inferior, $59 \%$, is the share of the nominal capital).

\section{[Insert Table 8 about here]}

The evolution of the amount and distribution of the industrial companies and of their capital gives evidence of a diverging behavior of the two series. While the absolute number grows by about $38 \%$, the amount of capital declines, thus confirming the negative trend of the mid-seventies already mentioned above. As for the number of initiatives, those industrial companies were allocated among different sectors as described in fig 1, concerning the number of initiatives: the most numerous categories were 'textiles', three fifths of which concentrated in Lombardy, Piedmont and Veneto; 'public and private construction', mostly located in Lombardy, Tuscany and Lazio; 'manufacturing' (an indistinct category which included chemical, mechanics and metallurgy), chiefly in Lombardy, Piedmont and Veneto and mining, especially in Tuscany (fig.2).

\section{[Insert here figures 1 and 2]}

As for capital, a part from the railways companies, it concentrated mostly in textiles, construction, manufacturing and trading companies as shown by fig. 8B. Lombardy alone absorbed more than half the capital of all the textile companies while Liguria held the primacy in construction. The paid up capital of the railways companies amounted to about 400 million liras, almost half the overall capital poured into the manufacturing sector and, as said, it was chiefly concentrated in Tuscany. A last word concerning 1876 has to be spent about foreign manufacturing companies, whose number (20) and capital (about 120 million Liras) was all but insignificant: about one third pertained to mining companies active in Sardinia, having their Italian headquarters in Cagliari.

Thus, the picture of the companies operating in Italy in 1876 does not show any particular change of distribution with respect to the two preceding benchmark years: the condition of inferiority of the South registered on the eve of unification unfortunately continued throughout the following 
decades; rather, some tiny improvement in both the number and the capital value shares was registered (see tab. 7). All in all, therefore, the picture which comes out from the data relative to the joint stock companies dynamics in the years immediately preceding and following the formation of the Italian Kingdom seems to confirm the hypothesis of an already existing differential between the North-Centre and the South.

On the contrary the Unification brought about some improvement, particularly in Sicily, where six companies (but mostly insurance) were created, as well as in Campania which almost doubled number and capital, improving mostly in the manufacturing sector. Certainly the image is not homogenous also with regard to the two macro-areas: in particular - as it has been already highlighted by the recent historiography (Fenoaltea 2003, Felice 2009, Daniele-Malanima 2011, Vecchi 2011) - the North/South differential seems to go hand in hand with a West-East differential as most Adriatic and Ionian regions shared throughout the period an astonishing lack of initiatives. In fact in the first two bench-mark years (1858 and 1865) all the eastern regions fronting the Adriatic Sea but Emilia (horizontally disposed throughout the peninsula and whose left boundary brushes against the Tyrrhenian Sea) totaled up respectively 4 and 7 initiatives against the 141 and 311 ones summed up by western and central regions. Only in 1876 the first group showed a timid awakening, as it registered 85 companies, yet hardly comparing with the 462 score of the other regions.

The years 1877-1882 represent the most critical period under the data profile. Up to 1881- as said - we dispose of two series aggregate at country level, the MAIC's and the Assonime's: as for the latter, it supplies data regarding both yearly births and stocks whilst on the contrary the MAIC series offers only stock data; besides, up to now no reliable data has been found for 1882 , whose value therefore has to be estimated. Such a shortcoming results even heavier as that year was the last one of the MAIC series, that is the best fitted to be linked the new one by BUSA beginning in 1883.

In any case those two series show up to 1881 quite similar trend, less so in the following years, as shown in fig. 3, whose values go back to 1872, the first year for which we dispose of the Assonime data $^{7}$. The MAIC+BUSA line in the 1880 S appears steeper than the Assonime's one. This sounds plausible as in this phase of the Italian history was characterized by a moderate economic

\footnotetext{
${ }^{7}$ the 1882 value has been estimated by increasing the 1881 data by 4,3\%, that is the \% change of the Assonime series in year 1882
} 
recovery during the government of the "Historical Left" coalition: it saw the abolition of the forced circulation and - mostly - the issue of the new civil code (1883) which finally liberalized the act of incorporation.

\section{[Insert here Figure 3]}

\section{The 1883-1914 period}

For the three following decades we dispose, as said, of a much larger empirical support, the dataset built on the massive information retrieved from the Bollettino Ufficiale delle Società per Azioni. In the following a few descriptive statistics elaborated from such source will be discussed, namely total entries and births both at the national and the local levels as well as the evolution of the companies' stock. Discussion of these data will allow us to produce a first basic contribution enlightening the general issues both of the long-term dynamics of Italian joint stock companies and of its unequal distribution throughout the peninsula. This data set will allow to readdress the discussion from the yearly net variations to the real births of companies, an entry rich of detailed data such as geographical location, sectoral allocation, nominal and paid up capital and so on.

A first glance at these thirty years is useful to figure out the "static" aspect of the data-base: on the whole the dimension of the data set is composed of 4954 entries. In other terms 4954 are the companies of which at least one piece of information has been recorded between 1883 and 1913: of these 3368 (i.e. 68\%) were headquartered in the North, $825(17 \%)$ in the Central regions and $683(15 \%)$ in the South. The sector allocation highlights the growth of the new sectors associated with the Second Industrial Revolution, such as metallurgy and engineering, chemicals, automobiles and public utilities, together with more traditional ones such as textiles and food-producing.

Although these figures do not have any dynamic value, they - by portraying the actual cumulated regional inequalities in the private capital formation - offer quite a convincing representation of the extraordinary uneven distribution of initiatives throughout the entire period, as well as the industrial advantage of the North: this was particularly true if one considers that cotton, silk, metallurgy and engineering were the sectors on which the industrial spurt of the second comers had lied. The most evident gap between the Northern regions and the other two macro-areas concerned textiles, whose aggregate share marked a value of $91 \%$ against $6 \%$ of the Central and $3 \%$ of the South. Within this category the two main sub-items - silk and cotton - resulted the more diverging: the first, silk, registered a Northern share of $96 \%$ vs. respectively $2 \%$ of the two 
other areas while an almost identical situation ( $95 \%$ vs. $2 \%$ in the Centre and $3 \%$ in the South) characterized cotton. Yet other critical categories such as automobiles, leather goods, metallurgy and engineering register a concentration of companies in the North around or even superior to $80 \%$ (for greater details see fig. 4 and table 9). Therefore these data show that the industrial and financial backwardness was not a peculiarity of the southern regions, as the total number of entries concentrated in the central regions of the peninsula was not much better that the ones in the South; here moreover there were a few categories - insurance, trade, banking and storage whose density was greater here than in Central Italy. But these were initiatives which certainly did not speak for an industrial drive of the Meridione, rather for a certain awakening of activities which had already had an ephemeral success in the Thirties, particularly in the Neapolitan area (Ostuni 1986, De Matteo 1984 and 1988).

\section{[Insert here Figure 4] \\ [Insert here table 9]}

The uneven distribution of entries of SAs throughout the country persuasively results also from their per-capita allocation by areas, that is from dividing the 1911 population of the three macroareas by the cumulated number of entries within each of them: while the country average yields a ratio of 1 company every 7093 inhabitants, the North shows a value of 1 to 4.584, the Center of 1 to 9020 and the South 1 to 16.401 . All in all these numbers give plain support to the hypothesis that the whole pre -World War 1 period didn't show any noticeable improvement vis-à-vis the pre-Unification years throughout the period up to World War 1.

Moving then to a first illustration of the S.A.s dynamics of the country, it has to be underlined that for this period we dispose of the complete series of data concerning numbers and nominal as well as paid-up capital. From these it clearly appears that the period is to be divided into two phases, reflecting the actual evolution of the Italian economic history: a first one of scarce economic vitality of the country - up to the late Nineties - and a second one, the so called "Giolittian age", corresponding to the first period of accelerated industrialization, characterized by a new vivacity of the financial sector of the country: limited companies, joint stock companies and mixed banks were to be the next protagonists of the economic boom of the first decade of the 20th century. Highly revealing is also the trend of the total companies listed at the stock exchange: at the Milan bourse, already the main one, between 1899 and 1907, their number grew from 45 to a historical 
peak of 168 , to oscillate in the following years at slightly lower values (Coltorti 2011, p.82) ${ }^{8}$. By the way, of the 158 companies listed in 1911, 131 had their headquarters in Northern Italy, 26 in Central and just 1 in the South (id. tab. 3.4, p.98)

Besides, the peculiar behavior of two new "German" banks (Banca Commerciale, 1894, and Credito Italiano, 1895) in fostering S.A.'s start-ups and expansion allows for the hypothesis that the capital raised by companies on the market with the banks' help (capital payments, capital increases, share premiums, debentures) approximated the total private industrial investment of the period (Pavese-Toninelli 1988, Warglien198, Confalonieri 1975/76 and 1982, Hertner 1984).

Such a dichotomy is empirically supported by tables 10 and 11. In fact of the 4286 new companies constituted in the entire $1883-1913$ period 4229 , only 728 , that is $17 \%$, of the total were the start-ups of the first 15 years, i.e. of the phase 1883 and 1898 . Yet this picture is only partially confirmed by the two series of the capital values: they certainly reflect the basic trend, however a few initiatives ${ }^{9}$ make this confrontation more balanced: with regard to the nominal capital, about $f 1246$ million out of 3,64 billion were raised in the first sub-period, that is $34 \%$ of the total, while a slightly greater percentage (38\%, i.e. $f 600.788 .000$ out of $f 1.561 .013 .000)$ concerned the paid-up capital.

[Insert here Table 10 and 11]

Moreover the data about the yearly average capital amount poured in new constitutions, and especially its standard deviation (cols. $b c$ and ef of tab. 11) further enlighten the difference between the first and second period: before 1898 the flow of new companies was less intense but more irregular because of the establishment of fewer - but not rarely bigger - entities (particularly in the financial sector); conversely in the new century the demography became more dynamic and regular with an evident increase of the manufacturing sector. In fact the standard deviation from the average annual nominal capital for the entire period was 4067, an average between a value

\footnotetext{
${ }^{8}$ These numbers almost doubled that of all the other local markets taken together. These numbers are slightly different from the ones reported in De Luca 2002

${ }^{9}$ Most of all, the incorporation in Milan in 1885 of the Società Italiana Strade Ferrate del Mediterraneo with a capital of 135 million Liras (40,5 paid up) and in 1894 of the Banca Commeriale Italiana with a capital of 10 million entirely paid up, in Rome in 1891 of the Istituto Italiano per il credito fondiario with a nominal capital of 100 million liras (40 million paid up) and in 1893 of the Banca d'Italia (respectively 210 and 63 million), in Naples in 1888 of the Società Risanamento Napoli (with 30 million Liras entirely paid up).
} 
of 6856 for the years $1883-1898$, and a much lower 1278 for the final fifteen years. The same could be said of the paid-up capital, with an overall standard deviation of 1671, a 1883-1898 value of 2889 and a $1899-1913$ SD of 748 . Looking at the market capitalization one can have a further confirmation of such a trend: in just ten years (from 1900 to 1910) the percentage of the bigger five $^{10}$ on the total market capitalization of the Italian companies dropped from $64 \%$ to $39 \%$ (Baia Curioni, 1995, tab. 4, p.12)

Getting more inside the yearly frequency, table 10 and fig. 5 point up a first rising cyclical movement reaching its maximum in 1899 (with 136 new charters) and a second one, much more pronounced, with its ceiling in 1907 (594 births), the year corresponding to the peak of the positive economic conjuncture of the belle époque. The trend in the following years decelerated, yet it stabilized around an average definitely superior to the one registered at the beginning of the century: as a matter of facts the years 1906 and 1907 registered respectively $12 \%$ and $14 \%$ of all the start-ups of the period; after that the percentage decreased to about $6 \%$.

\section{[Insert here Table 10 and 11] \\ [Insert here Figure 5]}

By detailing such trend at the macro-area level (fig.6) it emerges that it was mostly the result of an upsurge of the northern regions, which in those two years realized shares of respectively $83 \%$ (434) and $78 \%$ (466) of total new issues so that the gap with the other two areas was greatly enlarged; nor the deepening was to be recuperated next, even though the last two years, 1912 and 1913, marked a slight recovery of Central and Southern Italy.

\section{[Insert here Figure 6]}

Turning then to capital, nominal and paid up, the trend sketched above is only partly confirmed, because of the highly irregular behavior in the Eighties and early Nineties, due - as already observed - to a few heavy capitalized start-ups. However, after an evident depression in the mid90s, the cyclical movement became much clearer showing two pronounced peaks in 1899 and 1906 (see tabs. 12, 13 and fig. 7 \& 8).

[Insert here Table 12 and 13]

\footnotetext{
${ }^{10}$ i.e. Ferrovie Meridionali, Banca Commerciale Italiana, Ferrovie Mediterranee, Banca d'Italia, Terni in 1900 while in 1910 Terni was substituted by Credito Italiano
} 


\section{[Insert here Figure 7 \& 8]}

Also the share of paid up to nominal capital, which before 1894 had registered in a few years peaks between 70 and $84 \%$ (table 14), after that date decreased to values more in line with the mandate of the law, that is $33 \%$ (and $10 \%$ for the insurance companies). It might be of some interest to notice that if one excludes the mid Nineties - that is the worst years of the post 1883 Italian economy - connection with the two major positive swings (1899-1900 and 1905-1908), the average coverage of paid up to nominal capital was the lowest of the thirty years considered: one can reasonably suppose that this could have been the effect of the increasing speculative component of the financial market .

\section{[Insert here table 14]}

Finally with regard to the capital invested in the new constitutions, the Northern dominance is clearly confirmed as that area absorbed $69 \%$ of the total sum invested over the period both in nominal and paid up capital, while the southern share amounted respectively to just 8 and $10 \%$. However also here a certain difference comes out between the first decade and the following years, especially the 1892-1909 period, when minimal values were registered, just once reaching the two digits. It was probably in this period that an insurmountable cleavage between the South and the rest of the peninsula was created.

\section{Conclusions}

The aim of this paper was to evaluate if the traditionally neglected dynamics of limited and joinstock companies could help in explaining the actual evolution of the North-South economic differential, particularly with regard to the contrasting hypotheses between i) an original dualism already existing at time of the Unification of the peninsula and ii) conversely, a substantial leveled situation between the two areas, subsequently swept away by a national policy penalizing the economic conditions of the South.

\section{[Insert here Figure 9]}

Generally speaking, the results here produced seems to give support to the first hypothesis: as far as the private capital formation through constitutions and capital increases of joint-stock companies is concerned, the backwardness of the southern area stands throughout the entire 
period. In the three pre-1883 bench-mark years $(1858,1865,1876)$ the all-companies share of the North kept at levels greater than $60 \%$ (table 6 and fig. 9) , while the three values registered in the South stabilized on a much lower pace $(15 \%, 14 \%, 14 \%)$. It is true that the $\mathrm{K}$ scenario is quite different, as the heavy investment in two central regions (Tuscany and Lazio) had some displacement effect on the share of the other two areas; besides, South registered some increase (from 3 to 11\%) between 1865 and 1876, even though this was mainly due to banking and insurance: in fact looking just at the manufacturing activities, the share of the three subareas show a more consistent behavior, displaying once more clear divergences among them with the North keeping again on levels superior to $3 / 5$ (see table 8 ).

Moving then to the following period, it has been already shown that more than $2 / 3$ of the total entries of the 1883-1913 decades concerned the North: the South's outlier sectors were not the industrial ones, but banking (36\%), storage (30\%) and insurance (21\%). As for births undoubtedly the South registered a greater dynamism in the Eighties and in the post 1910 years, even though this was confined mostly to the same sectors plus transportation. Yet for most of the period (particularly in the 1892-1909 years) the behavior in the matter of capital investment was terribly diverging from the other two regions.

On the whole the share of capital poured into the most modern form of business organization kept very low; besides throughout the entire period, the South appeared particularly weak as far as the most crucial component of modern economic growth, that is manufacturing, is concerned. Therefore these data give further empirical support to the hypothesis that the actual pre-existing economic gap was considerably deepened after Unification, and particularly in the Giolittian age, when the northern regions scored for the first time significant progress. 
References

Acerbi G. (2011), Le società per azioni all'Unità d'Italia. I censimenti del 1865 e del 1866, Milano, II Sole-24 ore

ASSONIME (1928), Società italiane per azioni. Notizie statistiche, Roma, 1928

Baia Curioni S. (1995), Regolazione e competizione, Storia del mercato azionario in Italia, Bologna, il Mulino

Baskin B.J. - Miranti P. (1997), A History of Corporate Finance, Cambridge, Cambridge University Press

Brunetti A. , Felice E. \& Vecchi G. (2011), "Reddito" in G. Vecchi, In ricchezza e in povertà. Il benessere degli italiani dall'Unità a oggi, Bologna, il Mulino

Cafagna L. (1989), Dualismo e sviluppo nella storia d'Italia, Venezia, Marsilio, (originally published in 1971 with the title "La questione delle origini del dualismo economico italiano")

Cattaneo C. (1837)"Alcune ricerche sul progetto di un Monte delle sete", in Scritti sulla Lombardia, vol. II, Milano, 1967

Ciccarelli C. - Fenoaltea S. (2010) Through the Magnifying Glass: Provincial Aspects of Industrial Growth in Post-Unification Italy, Banca d'Italia - Quaderni di storia economica, n. 4, July 2010.

Coltorti F. (2011) "Banca, territorio e sviluppo economico", in Dall'Unità ai giorni nostri. 150 anni di borsa in Italia, Milano, Consob, 2011

Confalonieri A. (1975/6), Banca e industria in Italia, 1894-1906, 3 vv., Milano, Banca Commerciale Italiana

Confalonieri A. (1982), Banca e industria in Italia dalla crisi del 1907 all'agosto 1914, 2 vv., Milano, Banca Commerciale Italiana

Credito Italiano (vv.yy.) Notizie statistiche sulle principali società italiane per azioni, Milano, vv.yy.

Daniele V. - P.Malanima (2007) “Il prodotto delle regioni e il divario Nord-Sud in Italia (1861-1914)", in Rivista di politica economica , 97, pp.267-315

Daniele V. - P.Malanima (2011), Il divario Nord-Sud in Italia, 1861-2011, Soveria Mannelli, Rubettino

De Luca G. (2002) “Dall'economia industriale all'industria della finanza: le società quotate al listino azionario della Borsa di Milano dal 1861 al 2000", In Le società quotate alla borsa valori di Milano dal 1861 al 2000. Profili storici e titoli azionari, Milano, Libri Scheiwiller

De Matteo L. (1984), Holdings e sviluppo industriale nel Mezzogiorno: il caso della Società Industriale Partenopea (1833-18799, Napoli, Istituto Italiano per gli Studi Filosofici

(1988), "Protezionismo e sviluppo industriale nel Mezzogiorno preunitario" in Nuova Rivista Storica, LXXII

Federico G. (2007), “Ma l'agricoltura meridionale era davvero arretrata?" in Rivista di politica economica, 97, pp.317-40

Felice E. (2005), "Il valore aggiunto regionale. Una stima per il 1891 e per il 1911 e alcune elaborazioni di lungo periodo" in Rivista di storia economica, XXI 
(2009), "Estimating regional GDP in Italy (1871-2011): Sources, methodology and results". Universidad Carlos III de Madrid, Working papers in Economic History, n.7

(2014) Perché il Sud è rimasto indietro, Bologna

Fenoaltea S. (2003) “Peeking Backward: Regional Aspects of Industrial Growth in Post-Unification Italy", Journal of Economic History, 63, n. 4, pp. 1059-1102.

Freedeman C. (1979), Joint stock companies in France 1807-1867. From privileged company to modern corporation, Chapel Hill

Galor O. (2011), Unified growth theory, Princeton, Princeton Univ. Press

Giannetti R. - Vasta M. (2006), Evolution of Italian enterprises in the 20th century, Heidelberg-N.York 2006

Hannah L. 1976, The Rise Of The Corporate Economy, London

(2013), A Global Census Of Corporations in 1910, CIRJE Discussion paper F-878, Tokio

(2013b), The corporate economies of America and Europe, CIRJE Discussion paper F-877, Tokio

Harris R. (2000), Industrializing English law: Entrepreneurship and business organization, Cambridge London

Hertner P.(1990) II capitale tedesco in Italia dall'unità alla Prima guerra mondiale. Banche miste e sviluppo economico, Bologna, il Mulino

Kuznets S. (1966), Modern Economic Growth: Rate, Structure And Spread, New Haven

Landes D. (1978), The Unbound Prometheus: Technological Change and Industrial Development in Western Europe from 1750 to the Present, Cambridge, CUP

Landes D. (1998), The Wealth and Poverty of Nations: Why Are Some So Rich and Others So Poor? New York: W.W. Norton, 1998

MAIC (1865) Quadro delle società industriali, commerciali e finanziarie anonime ed in accomandita per azioni al portatore costituitesi nelle province che ora formano il Regno d'Itali dal 1845 al 1864a, compilato per cura del Ministero d'Agricoltura, Industria e commercio, Torino, Tipografia e Libreria editrice del regno d'Italia - G. Faziola e C.

MAIC (1866) Statistica del Regno d'Italia. Commercio. Società commerciali e industriali. Anno 1865, Firenze, Tipografia Tofani, 1866

MAIC (1877), Statistica ed elenco generale degli Istituti di credito e della società per azioni nazionali ed estere esistenti nel regno al 31 dicembre 1876, Roma 1877

MAIC (1882) Annali dell'industria

Nitti F. (1900) Nord e Sud, Torino, Roux e Viarengo

Ostuni N. (1986), Le società per azioni dal 1818 al 1834, Napoli, Facoltà di Economia marittima 
Pavese C. - Toninelli P.A. (1988) "L'andamento e la distribuzione degli investimenti industriali in Italia (1894-1914). Metodologia e primi risultati”, in L. Avagliano (ed.), L'Italia industriale nelle sue regioni: bilancio storiografico, Napoli ESI,1988

Pepelasis I.S. -Emmanouilidi E. (2013), JointStock Company births: historical coincidence and economic causality, WP Series 13 - 2013, Athens University of Economics and Business

Perrotta C. (2012), “Medioevo. Lo sviluppo soffocato sul nascere”, in Perrotta-Sunna 2012

Perrotta C. - Sunna C. (2012), eds. L'arretratezza del Mezzogiorno. Le idee, l'economia, la storia, Milano, Bruno Mondadori

Piccinelli F. (1902) Le società industriali italiane per azioni, Milano

Schumpeter J. (1942), Capitalism, socialism and democracy, New York

Sombart W. (1967) Il capitalismo moderno, Torino

Sylla R. (2002) Financial Systems and Economic Modernization, Journal of Economic History, 62, 2

Sylla R. \& Wright R. (2011) "Corporate Governance and Stockholder/Stakeholder Activism in the United States, 1790-1860," in Origins of Shareholder Advocacy , Jonathan Koppell ed., New York

Tremelloni (1947), Storia dell'industria contemporanea. Dalla fine del Settecento all'Unità d'Italia, Torino

G. Viesti, Abolire il Mezzogiorno, Roma-Bari 2003

Warglien M (1987), “Investimento industriale e instabilità finanziaria in Italia, 1878-1913", in Rivista di storia economica, n.s. n.3

Wright R. (2011), "Corporate entrepreneurship in the Antebellum South", in The transformation of the Southern Society (ed. by S. Delfino at al.), Columbia (MO) 
TABELLA 1. The JSC in 1858

\begin{tabular}{|c|c|c|c|c|c|c|c|c|c|c|}
\hline 1858 & \multicolumn{2}{|c|}{ All } & \multicolumn{2}{|c|}{ Insurance } & \multicolumn{2}{|c|}{ Banks } & \multicolumn{2}{|c|}{ Railroads } & \multicolumn{2}{|c|}{ Manufacturing } \\
\hline & $\#$ & $\mathrm{~K} 000$ & $\#$ & k 000 & $\#$ & k 000 & $\#$ & k 000 & $\#$ & $\mathrm{k} 000$ \\
\hline Piemonte & 35 & 103216 & 7 & 15160 & 1 & 40000 & 5 & 16015 & 22 & 31951 \\
\hline Liguria & 25 & 39970 & 12 & 9640 & 2 & 12000 & 1 & 3000 & 10 & 15330 \\
\hline Lombardia & 27 & 23027 & 3 & 1509 & 0 & 0 & 2 & 12500 & 22 & 9018 \\
\hline Emilia & 9 & 5822 & 0 & 0 & 2 & 479 & 0 & 0 & 7 & 5336 \\
\hline Umbria & 1 & 3192 & 0 & 0 & 0 & 0 & 0 & 0 & 1 & 3192 \\
\hline Marche & 3 & 10665 & 1 & 399 & 2 & 10266 & 0 & 0 & 0 & 0 \\
\hline Toscana & 29 & 120282 & 2 & 5250 & 2 & 10504 & 1 & 10382 & 24 & 94146 \\
\hline Abruzzi & 0 & 0 & 0 & 0 & 0 & 0 & 0 & 0 & 0 & 0 \\
\hline Campania & 21 & 23406 & 13 & 10158 & 0 & 0 & 0 & 0 & 9 & 13248 \\
\hline Puglia & 1 & 25 & 0 & 0 & 0 & 0 & 0 & 0 & 1 & 25 \\
\hline Basilicata & 0 & 0 & 0 & 0 & 0 & 0 & 0 & 0 & 0 & 0 \\
\hline Calabria & 0 & 0 & 0 & 0 & 0 & 0 & 0 & 0 & 0 & 0 \\
\hline Sicilia & 0 & 0 & 0 & 0 & 0 & 0 & 0 & 0 & 0 & 0 \\
\hline Sardegna & 0 & 0 & 0 & 0 & 0 & 0 & 0 & 0 & 0 & 0 \\
\hline TOTAL & 151 & 329605 & 38 & 48172 & 9 & 73249 & 9 & 43382 & 96 & 191803 \\
\hline NORTH & 96 & 170035 & 22 & 26309 & 5 & 52479 & 8 & 31315 & 61 & 616352 \\
\hline CENTRAL & 33 & 134139 & 3 & 5649 & 4 & 20770 & 1 & 10382 & 25 & 97338 \\
\hline SOUTH* & 23 & 23431 & 13 & 10158 & 0 & 0 & 0 & 0 & 10 & 40273 \\
\hline l & 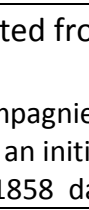 & $\mathrm{AIC}$ & Q & delles & & ali; $\mathrm{M}$ & & tistica & Rean & $y^{\prime}$ Italia \\
\hline
\end{tabular}

\begin{tabular}{|r|r|r|r|}
\hline \multicolumn{5}{|c|}{ Tab.2 - The JSC dynamics $1858-65$} \\
\hline & \multicolumn{1}{|c|}{$\boldsymbol{\#}$} & \multicolumn{1}{|c|}{$\boldsymbol{\Delta}$} & \\
\hline 1858 & 151 & 329605 & 151 \\
\hline 1859 & 11 & 57432 & 162 \\
\hline 1860 & 13 & 57306 & 175 \\
\hline 1861 & 20 & 16727 & 195 \\
\hline 1862 & 35 & 535700 & 230 \\
\hline 1863 & 40 & 524469 & 240 \\
\hline 1864 & 46 & 153953 & 286 \\
\hline 1865 & 27 & 717425 & 343 \\
\hline Tot 1865 & 343 & 2392617 & \\
\hline \multicolumn{4}{|l}{ Source: see text } \\
\hline
\end{tabular}




\begin{tabular}{|c|c|c|c|c|}
\hline \multicolumn{5}{|c|}{ Table 3: 1865 , all JSC } \\
\hline & $\#$ & & K 000 & \\
\hline Piemonte & 75 & $22 \%$ & 1063346 & $44,4 \%$ \\
\hline Liguria & 57 & $17 \%$ & 53336 & $2,2 \%$ \\
\hline Lombardia & 69 & $20 \%$ & 75737 & $3,2 \%$ \\
\hline Emilia & 17 & $5 \%$ & 8386 & $0,4 \%$ \\
\hline Umbria & 3 & $1 \%$ & 3442 & $0,1 \%$ \\
\hline Marche & 6 & $2 \%$ & 1094 & $0,0 \%$ \\
\hline Toscana & 69 & $20 \%$ & 1109115 & $46,4 \%$ \\
\hline Campania & 38 & $11 \%$ & 40925 & $1,7 \%$ \\
\hline Puglia & 1 & $0 \%$ & 25 & $0,0 \%$ \\
\hline Sicilia & 6 & $2 \%$ & 10070 & $0,4 \%$ \\
\hline Sardegna & 2 & $1 \%$ & 27150 & $1,1 \%$ \\
\hline TOTALE & 343 & $100 \%$ & 2392627 & $100,0 \%$ \\
\hline NORD & 218 & $63,6 \%$ & 1200805 & $50 \%$ \\
\hline CENTRO & 78 & $22,7 \%$ & 1113651 & $47 \%$ \\
\hline SUD & 47 & $13,7 \%$ & 78170 & $3 \%$ \\
\hline Source: see & & & & \\
\hline
\end{tabular}

\begin{tabular}{|c|c|c|c|c|}
\hline \multicolumn{4}{|c|}{ Tab.4 - 1865, Manufacturing } & \multirow[b]{2}{*}{$\%$} \\
\hline & $\#$ & $\%$ & $\mathrm{~K} 000$ & \\
\hline Piemonte & 44 & $21,6 \%$ & 236736 & $49,0 \%$ \\
\hline Liguria & 13 & $6,4 \%$ & 16306 & $3,4 \%$ \\
\hline Lombardia & 57 & $27,9 \%$ & 38728 & $8,0 \%$ \\
\hline Emilia & 12 & $5,9 \%$ & 6137 & $1,3 \%$ \\
\hline Umbria & 3 & $1,5 \%$ & 3442 & $0,7 \%$ \\
\hline Marche & 2 & $1,0 \%$ & 409 & $0,1 \%$ \\
\hline Toscana & 51 & $25,0 \%$ & 117424 & $24,3 \%$ \\
\hline Campania & 17 & $8,3 \%$ & 28216 & $5,8 \%$ \\
\hline Puglia & 1 & $0,5 \%$ & 25 & $0,0 \%$ \\
\hline Sicilia & 2 & $1,0 \%$ & 8765 & $1,8 \%$ \\
\hline Sardegna & 2 & $1,0 \%$ & 27150 & $5,6 \%$ \\
\hline TOTALE & 204 & $100 \%$ & 483340 & $100,0 \%$ \\
\hline North & 126 & $62 \%$ & 297907 & $61,6 \%$ \\
\hline Central & 56 & $27 \%$ & 121275 & $25,1 \%$ \\
\hline South & 22 & $11 \%$ & 64156 & $13,3 \%$ \\
\hline
\end{tabular}




\begin{tabular}{|c|c|c|c|}
\hline \multicolumn{4}{|c|}{$\begin{array}{c}\text { Tab } 5 \text { - Yearly stock and flow } \\
\text { values }\end{array}$} \\
\hline & $\#$ & $\Delta \#$ & $\Delta K$ \\
\hline 1858 & 152 & & 329605 \\
\hline 1859 & 163 & 11 & 387037 \\
\hline 1860 & 176 & 13 & 444343 \\
\hline 1861 & 196 & 20 & 461070 \\
\hline 1862 & 231 & 35 & 996770 \\
\hline 1863 & 271 & 40 & 1521239 \\
\hline 1864 & 317 & 46 & 1675192 \\
\hline 1865 & 343 & 26 & 2392617 \\
\hline 1866 & 243 & -100 & 1420645 \\
\hline 1867 & 291 & 48 & 1419145 \\
\hline *1868 & 325 & 34 & 1497989 \\
\hline 1869 & 359 & 34 & 1576834 \\
\hline 1870 & 422 & 63 & 1706658 \\
\hline 1871 & 522 & 100 & 2006206 \\
\hline 1872 & 595 & 73 & 2320137 \\
\hline 73 & 719 & 124 & 2741536 \\
\hline 74 & 717 & -2 & 2558376 \\
\hline 75 & 716 & -1 & 2413703 \\
\hline 76 & 643 & -73 & 1962647 \\
\hline 77 & 619 & -24 & 1912471 \\
\hline 78 & 615 & -4 & 1982601 \\
\hline 79 & 621 & 6 & 1998677 \\
\hline 1880 & 644 & 23 & 1991660 \\
\hline 81 & 716 & 72 & 2380463 \\
\hline
\end{tabular}

\begin{tabular}{|l|r|r|r|r|r|r|}
\hline \multicolumn{7}{|c|}{ TAB. 6: The JSC dynamics (1858-1876) } \\
\hline & \multicolumn{3}{|c|}{ NUMBER } & \multicolumn{3}{|c|}{ K pair values } \\
\hline & 1858 & 1865 & 1876 & 1858 & 1865 & 1876 \\
\hline NORTH & $63,6 \%$ & $63,6 \%$ & $61 \%$ & $52 \%$ & $50 \%$ & $45 \%$ \\
\hline CENTRAL & $21,9 \%$ & $22,7 \%$ & $25 \%$ & $41 \%$ & $47 \%$ & $44 \%$ \\
\hline SOUTH & $14,5 \%$ & $13,7 \%$ & $14 \%$ & $7 \%$ & $3 \%$ & $11 \%$ \\
\hline
\end{tabular}




\begin{tabular}{|l|r|r|r|r|r|r|}
\hline \multicolumn{7}{|c|}{ Tab 7 - 1876 \# and K of all jsc } \\
\hline \multicolumn{1}{|c|}{ 1876 } & \multicolumn{1}{|c|}{ \# } & \multicolumn{2}{c|}{ K Nom } & \multicolumn{2}{c|}{ K paid up } \\
\hline & \multicolumn{1}{|c|}{$\%$} & \multicolumn{1}{c|}{ K } & \multicolumn{1}{c|}{$\%$} & \multicolumn{1}{c|}{ K } & \multicolumn{1}{c|}{$\%$} \\
\hline Piemonte & 92 & $14 \%$ & 254085 & $12 \%$ & 191924 & $15 \%$ \\
\hline Liguria & 70 & $11 \%$ & 300156 & $15 \%$ & 118141 & $9 \%$ \\
\hline Lombardia & 118 & $18 \%$ & 257243 & $13 \%$ & 144187 & $11 \%$ \\
\hline Veneto & 64 & $10 \%$ & 64246 & $3 \%$ & 36451 & $3 \%$ \\
\hline Emilia & 49 & $8 \%$ & 42729 & $2 \%$ & 26940 & $2 \%$ \\
\hline Umbria & 6 & $1 \%$ & 527 & $0 \%$ & 290 & $0 \%$ \\
\hline Marche & 15 & $2 \%$ & 4207 & $0 \%$ & 3591 & $0 \%$ \\
\hline Toscana & 100 & $16 \%$ & 489131 & $24 \%$ & 386423 & $29 \%$ \\
\hline Lazio & 39 & $6 \%$ & 413479 & $20 \%$ & 258905 & $20 \%$ \\
\hline Abruzzi & 2 & $0 \%$ & 418 & $0 \%$ & 339 & $0 \%$ \\
\hline Campania & 37 & $6 \%$ & 128158 & $6 \%$ & 82351 & $6 \%$ \\
\hline Puglia & 4 & $1 \%$ & 925 & $0 \%$ & 749 & $0 \%$ \\
\hline basilicata & 1 & $0 \%$ & 30 & $0 \%$ & 28 & $0 \%$ \\
\hline Calabria & 1 & $0 \%$ & 86 & $0 \%$ & 65 & $0 \%$ \\
\hline Sicilia & 27 & $4 \%$ & 41726 & $2 \%$ & 27743 & $2 \%$ \\
\hline Sardegna & 18 & $3 \%$ & 48199 & $2 \%$ & 43193 & $3 \%$ \\
\hline & 643 & $100 \%$ & 2045345 & $100 \%$ & 1321320 & $100 \%$ \\
\hline & & & & & & \\
\hline NORD & 393 & $61 \%$ & 918459 & $45 \%$ & 517643 & $39 \%$ \\
\hline CENTRO & 162 & $25 \%$ & 907762 & $44 \%$ & 649548 & $49 \%$ \\
\hline SUD & 88 & $14 \%$ & 219124 & $11 \%$ & 154129 & $12 \%$ \\
\hline & 643 & $100 \%$ & 2045345 & $100 \%$ & 1321320 & $100 \%$ \\
\hline
\end{tabular}

Source: see text

\begin{tabular}{|l|r|r|r|r|r|r|r|}
\hline \multicolumn{8}{|c|}{ Tab. 8: manufacturing allocation by areas } \\
\hline & \multicolumn{3}{|c|}{ \# MANUF. } & \multicolumn{5}{c|}{ K MANUF. } \\
\hline & 1858 & 1865 & 1876 & 1858 & 1865 & \multicolumn{2}{c|}{1876} \\
\hline & & & & & & (a) paid up & (b) nom. \\
\hline TOTALE & $100 \%$ & $100 \%$ & $100 \%$ & $100 \%$ & $100 \%$ & $100 \%$ & $100 \%$ \\
\hline North & $64 \%$ & $62 \%$ & $62 \%$ & $36 \%$ & $62 \%$ & $61 \%$ & $59 \%$ \\
\hline Central & $26 \%$ & $27 \%$ & $26 \%$ & $57 \%$ & $25 \%$ & $21 \%$ & $25 \%$ \\
\hline South & $10 \%$ & $11 \%$ & $12 \%$ & $8 \%$ & $13 \%$ & $18 \%$ & $16 \%$ \\
\hline
\end{tabular}


Tab. 9 - Regional entries by sector (1882-1913)

\begin{tabular}{|c|c|c|c|c|c|c|c|}
\hline & North & Central & South & Total & North & Central & South \\
\hline 1. Tourism & 171 & 43 & 23 & 237 & $72 \%$ & $18 \%$ & $10 \%$ \\
\hline 2. Aliment. & 280 & 78 & 74 & 432 & $65 \%$ & $18 \%$ & $17 \%$ \\
\hline 3. Insurance & 67 & 16 & 23 & 106 & $63 \%$ & $16 \%$ & $21 \%$ \\
\hline 4. Auto & 69 & 10 & 7 & 86 & $80 \%$ & $8 \%$ & $12 \%$ \\
\hline 5. Cement \& building & 186 & 69 & 29 & 284 & $66 \%$ & $24 \%$ & $10 \%$ \\
\hline 6.Chemical & 240 & 61 & 31 & 332 & $72 \%$ & $18 \%$ & $9 \%$ \\
\hline 7.Trade & 190 & 38 & 47 & 275 & $69 \%$ & $14 \%$ & $17 \%$ \\
\hline 8. Banking & 188 & 83 & 176 & 447 & $45 \%$ & $20 \%$ & $36 \%$ \\
\hline 9. Utilities & 336 & 88 & 70 & 494 & $68 \%$ & $17 \%$ & $14 \%$ \\
\hline 10. Mining & 104 & 39 & 15 & 158 & $67 \%$ & $24 \%$ & $9 \%$ \\
\hline 11. Real Estate & 179 & 59 & 20 & 258 & $71 \%$ & $22 \%$ & $7 \%$ \\
\hline 12.Lumber & 67 & 12 & 12 & 91 & $73 \%$ & $13 \%$ & $13 \%$ \\
\hline 13.Storage \& Ice & 55 & 8 & 28 & 91 & $60 \%$ & $10 \%$ & $30 \%$ \\
\hline 14. Metallurgy \& Eng. & 382 & 62 & 41 & 485 & $79 \%$ & $13 \%$ & $9 \%$ \\
\hline 15. Leather goods & 37 & 3 & 4 & 44 & $84 \%$ & $7 \%$ & $9 \%$ \\
\hline 16.Printing \& Publ. & 114 & 53 & 22 & 189 & $60 \%$ & $28 \%$ & $12 \%$ \\
\hline 17.Textiles & 357 & 23 & 13 & 394 & $91 \%$ & $6 \%$ & $3 \%$ \\
\hline 17a.Silk & 40 & 1 & 1 & 42 & $95 \%$ & $2 \%$ & $2 \%$ \\
\hline 17b.wool & 41 & 4 & & 45 & $91 \%$ & $9 \%$ & $0 \%$ \\
\hline 17c. Cott. & 147 & 3 & 4 & 154 & $95 \%$ & $2 \%$ & $3 \%$ \\
\hline 17d. other & 130 & 15 & 8 & 153 & $85 \%$ & $9 \%$ & $5 \%$ \\
\hline 18. Transport & 261 & 87 & 78 & 426 & $62 \%$ & $20 \%$ & $18 \%$ \\
\hline 18b. Rails & 47 & 23 & 160 & 230 & $70 \%$ & $20 \%$ & $10 \%$ \\
\hline 19. Ital.abroad* & 24 & 4 & 3 & 31 & $78 \%$ & $13 \%$ & $9 \%$ \\
\hline \multirow[t]{2}{*}{ 20.Other } & 61 & 19 & 15 & 95 & $61 \%$ & $22 \%$ & $17 \%$ \\
\hline & 3368 & 855 & 731 & 4954 & $68 \%$ & $17 \%$ & $15 \%$ \\
\hline
\end{tabular}

Source: see text 
Tab. 10: JSC BIRTHS BY AREA (number)

\begin{tabular}{|c|c|c|c|c|c|c|c|c|c|}
\hline & NORTH & & CENTRAL & & SOUTH & & TOTAL & & \\
\hline 1883 & 43 & $68 \%$ & 4 & $6 \%$ & 16 & $25 \%$ & 63 & $100 \%$ & \\
\hline 1884 & 28 & $57 \%$ & 14 & $29 \%$ & 7 & $14 \%$ & 49 & $100 \%$ & \\
\hline 1885 & 42 & $52 \%$ & 16 & $20 \%$ & 23 & $28 \%$ & 81 & $100 \%$ & \\
\hline 1886 & 22 & $42 \%$ & 11 & $21 \%$ & 19 & $37 \%$ & 52 & $100 \%$ & \\
\hline 1887 & 30 & $41 \%$ & 14 & $19 \%$ & 29 & $40 \%$ & 73 & $100 \%$ & \\
\hline 1888 & 29 & $57 \%$ & 11 & $22 \%$ & 11 & $22 \%$ & 51 & $100 \%$ & \\
\hline 1889 & 37 & $67 \%$ & 5 & $9 \%$ & 13 & $24 \%$ & 55 & $100 \%$ & \\
\hline 1890 & 26 & $70 \%$ & 6 & $16 \%$ & 5 & $14 \%$ & 37 & $100 \%$ & \\
\hline 1891 & 22 & $63 \%$ & 6 & $17 \%$ & 7 & $20 \%$ & 35 & $100 \%$ & \\
\hline 1892 & 23 & $74 \%$ & 5 & $16 \%$ & 3 & $10 \%$ & 31 & $100 \%$ & \\
\hline 1893 & 17 & $65 \%$ & 6 & $23 \%$ & 3 & $12 \%$ & 26 & $100 \%$ & \\
\hline 1894 & 19 & $70 \%$ & 6 & $22 \%$ & 2 & $7 \%$ & 27 & $100 \%$ & \\
\hline 1895 & 18 & $78 \%$ & 3 & $13 \%$ & 2 & $9 \%$ & 23 & $100 \%$ & \\
\hline 1896 & 27 & $79 \%$ & 2 & $6 \%$ & 5 & $15 \%$ & 34 & $100 \%$ & \\
\hline 1897 & 25 & $71 \%$ & 4 & $11 \%$ & 6 & $17 \%$ & 35 & $100 \%$ & \\
\hline 1898 & 42 & $75 \%$ & 7 & $13 \%$ & 7 & $13 \%$ & 56 & $100 \%$ & \\
\hline 1899 & 104 & $76 \%$ & 20 & $15 \%$ & 12 & $9 \%$ & 136 & $100 \%$ & 28 \\
\hline 1900 & 76 & $75 \%$ & 15 & $15 \%$ & 10 & $10 \%$ & 101 & $100 \%$ & \\
\hline 1901 & 49 & $61 \%$ & 13 & $16 \%$ & 18 & $23 \%$ & 80 & $100 \%$ & \\
\hline 1902 & 48 & $65 \%$ & 9 & $12 \%$ & 17 & $23 \%$ & 74 & $100 \%$ & \\
\hline 1903 & 62 & $63 \%$ & 14 & $14 \%$ & 22 & $22 \%$ & 98 & $100 \%$ & \\
\hline 1904 & 83 & $65 \%$ & 23 & $18 \%$ & 21 & $17 \%$ & 127 & $100 \%$ & \\
\hline 1905 & 241 & $77 \%$ & 52 & $17 \%$ & 22 & $7 \%$ & 315 & $100 \%$ & \\
\hline 1906 & 434 & $83 \%$ & 59 & $11 \%$ & 29 & $6 \%$ & 522 & $100 \%$ & \\
\hline 1907 & 466 & $78 \%$ & 88 & $15 \%$ & 40 & $7 \%$ & 594 & $100 \%$ & \\
\hline 1908 & 207 & $67 \%$ & 66 & $21 \%$ & 37 & $12 \%$ & 310 & $100 \%$ & \\
\hline 1909 & 177 & $64 \%$ & 54 & $20 \%$ & 45 & $16 \%$ & 276 & $100 \%$ & \\
\hline 1910 & 151 & $63 \%$ & 34 & $14 \%$ & 55 & $23 \%$ & 240 & $100 \%$ & \\
\hline 1911 & 140 & $62 \%$ & 42 & $19 \%$ & 45 & $20 \%$ & 227 & $100 \%$ & \\
\hline 1912 & 129 & $55 \%$ & 54 & $23 \%$ & 52 & $22 \%$ & 235 & $100 \%$ & \\
\hline \multirow[t]{2}{*}{1913} & 127 & $57 \%$ & 57 & $26 \%$ & 39 & $17 \%$ & 223 & $100 \%$ & \\
\hline & 2944 & $69 \%$ & 720 & $17 \%$ & 622 & $15 \%$ & 4286 & $100 \%$ & \\
\hline
\end{tabular}

Source: see text 


\begin{tabular}{|c|c|c|c|c|c|c|}
\hline \multicolumn{7}{|c|}{ tab. 11 - Nominal and paid up K ( $£ \times 000)$} \\
\hline & Nominal $K$ & & & Paid up K & & \\
\hline & $\Sigma$ & average & $\mathrm{sd}$ & $\Sigma$ & average & sd \\
\hline 1883 & 135835 & 2156 & 4380 & 95561 & 1517 & 3015 \\
\hline 1884 & 87014 & 1776 & 5906 & 50753 & 1036 & 3059 \\
\hline 1885 & 228663 & 2823 & 15145 & 92721 & 1145 & 4844 \\
\hline 1886 & 54396 & 1046 & 1605 & 24201 & 465 & 1076 \\
\hline 1887 & 75826 & 1039 & 1642 & 36496 & 500 & 1308 \\
\hline 1888 & 79007 & 1549 & 4283 & 67052 & 1315 & 4255 \\
\hline 1889 & 53125 & 966 & 1634 & 20304 & 369 & 657 \\
\hline 1890 & 34258 & 926 & 1568 & 24313 & 657 & 1314 \\
\hline 1891 & 115361 & 3296 & 16844 & 50209 & 1435 & 6742 \\
\hline 1892 & 15241 & 492 & 665 & 8346 & 269 & 450 \\
\hline 1893 & 223084 & 8580 & 41087 & 67994 & 2615 & 12318 \\
\hline 1894 & 18385 & 681 & 1939 & 13595 & 504 & 1908 \\
\hline 1895 & 11328 & 493 & 891 & 3593 & 156 & 279 \\
\hline 1896 & 22454 & 660 & 1072 & 8118 & 239 & 358 \\
\hline 1897 & 18022 & 515 & 1370 & 4908 & 140 & 325 \\
\hline 1898 & 74173 & 1325 & 2809 & 32624 & 583 & 1430 \\
\hline 1899 & 246639 & 1814 & 2581 & 75029 & 552 & 782 \\
\hline 1900 & 111106 & 1100 & 1422 & 39675 & 393 & 586 \\
\hline 1901 & 49374 & 617 & 1287 & 26583 & 332 & 1088 \\
\hline 1902 & 44815 & 606 & 1220 & 16080 & 217 & 384 \\
\hline 1903 & 70489 & 719 & 1559 & 36125 & 369 & 1325 \\
\hline 1904 & 112140 & 883 & 1702 & 47806 & 376 & 1003 \\
\hline 1905 & 349888 & 1111 & 1803 & 127164 & 404 & 665 \\
\hline 1906 & 448601 & 859 & 1315 & 156839 & 300 & 483 \\
\hline 1907 & 343140 & 578 & 776 & 133966 & 226 & 333 \\
\hline 1908 & 110728 & 357 & 483 & 43432 & 140 & 205 \\
\hline 1909 & 93871 & 340 & 678 & 37679 & 137 & 300 \\
\hline 1910 & 115527 & 481 & 1290 & 49604 & 207 & 608 \\
\hline 1911 & 79899 & 352 & 727 & 40016 & 176 & 431 \\
\hline 1912 & 104054 & 443 & 960 & 62747 & 267 & 625 \\
\hline \multirow[t]{2}{*}{1913} & 118038 & 529 & 1370 & 67480 & 303 & 978 \\
\hline & 3644481 & 1262 & 3936 & 1561013 & 559 & 1714 \\
\hline
\end{tabular}

Source: see text 


\section{tab 12: JSC BIRTHS BY AREA (nominal K)}

\begin{tabular}{|c|c|c|c|c|c|c|}
\hline NORTH & & CENTRAL & & SOUTH & & TOTAL \\
\hline 97603 & $72 \%$ & 15050 & $11 \%$ & 23182 & $17 \%$ & 135835 \\
\hline 67410 & $77 \%$ & 17659 & $20 \%$ & 1945 & $2 \%$ & 87014 \\
\hline 179109 & $78 \%$ & 28757 & $13 \%$ & 20797 & $9 \%$ & 228663 \\
\hline 23248 & $43 \%$ & 17219 & $32 \%$ & 13929 & $26 \%$ & 54396 \\
\hline 44978 & $59 \%$ & 15204 & $20 \%$ & 15644 & $21 \%$ & 75826 \\
\hline 38280 & $48 \%$ & 5977 & $8 \%$ & 34750 & $44 \%$ & 79007 \\
\hline 47769 & $90 \%$ & 1759 & $3 \%$ & 3597 & $7 \%$ & 53125 \\
\hline 23684 & $69 \%$ & 7269 & $21 \%$ & 3305 & $10 \%$ & 34258 \\
\hline 10420 & $9 \%$ & 100460 & $87 \%$ & 4481 & $4 \%$ & 115361 \\
\hline 11124 & $73 \%$ & 3941 & $26 \%$ & 176 & $1 \%$ & 15241 \\
\hline 8434 & $4 \%$ & 214400 & $96 \%$ & 250 & $0 \%$ & 223084 \\
\hline 15385 & $84 \%$ & 2600 & $14 \%$ & 400 & $2 \%$ & 18385 \\
\hline 8485 & $75 \%$ & 2615 & $23 \%$ & 228 & $2 \%$ & 11328 \\
\hline 20760 & $92 \%$ & 877 & $4 \%$ & 817 & $4 \%$ & 22454 \\
\hline 15872 & $88 \%$ & 1250 & $7 \%$ & 900 & $5 \%$ & 18022 \\
\hline 48066 & $65 \%$ & 23776 & $32 \%$ & 2331 & $3 \%$ & 74173 \\
\hline 193661 & $79 \%$ & 39095 & $16 \%$ & 13883 & $6 \%$ & 246639 \\
\hline 96992 & $87 \%$ & 8734 & $8 \%$ & 5380 & $5 \%$ & 111106 \\
\hline 43468 & $88 \%$ & 3090 & $6 \%$ & 2816 & $6 \%$ & 49374 \\
\hline 30835 & $69 \%$ & 5410 & $12 \%$ & 8570 & $19 \%$ & 44815 \\
\hline 52329 & $74 \%$ & 13940 & $20 \%$ & 4220 & $6 \%$ & 70489 \\
\hline 71605 & $64 \%$ & 30103 & $27 \%$ & 10432 & $9 \%$ & 112140 \\
\hline 289729 & $83 \%$ & 43165 & $12 \%$ & 16994 & $5 \%$ & 349888 \\
\hline 394837 & $88 \%$ & 33179 & $7 \%$ & 20585 & $5 \%$ & 448601 \\
\hline 292347 & $85 \%$ & 41851 & $12 \%$ & 8942 & $3 \%$ & 343140 \\
\hline 86067 & $78 \%$ & 16984 & $15 \%$ & 7677 & $7 \%$ & 110728 \\
\hline 62726 & $67 \%$ & 21672 & $23 \%$ & 9473 & $10 \%$ & 93871 \\
\hline 66934 & $58 \%$ & 30203 & $26 \%$ & 18390 & $16 \%$ & 115527 \\
\hline 53284 & $67 \%$ & 8765 & $11 \%$ & 17850 & $22 \%$ & 79899 \\
\hline 65561 & $63 \%$ & 28096 & $27 \%$ & 10397 & $10 \%$ & 104054 \\
\hline 61141 & $52 \%$ & 40610 & $34 \%$ & 16287 & $14 \%$ & 118038 \\
\hline 2522143 & $69 \%$ & 823710 & $23 \%$ & 298628 & $8 \%$ & 3644481 \\
\hline
\end{tabular}

Source: see text 


\begin{tabular}{|c|c|c|c|c|c|c|c|c|}
\hline \multicolumn{9}{|c|}{ tab 13: JSC BIRTHS BY AREA (paid up K) } \\
\hline & NORTH & & CENTRAL & & SOUTH & & TOTAL & \\
\hline 1883 & 70770 & $74 \%$ & 9880 & $10 \%$ & 14911 & $16 \%$ & 95561 & $100 \%$ \\
\hline 1884 & 41037 & $81 \%$ & 8399 & $17 \%$ & 1317 & $3 \%$ & 50753 & $100 \%$ \\
\hline 1885 & 60662 & $65 \%$ & 21274 & $23 \%$ & 10785 & $12 \%$ & 92721 & $100 \%$ \\
\hline 1886 & 8477 & $35 \%$ & 10566 & $44 \%$ & 5158 & $21 \%$ & 24201 & $100 \%$ \\
\hline 1887 & 26030 & $71 \%$ & 5262 & $14 \%$ & 5204 & $14 \%$ & 36496 & $100 \%$ \\
\hline 1888 & 31175 & $46 \%$ & 3147 & $5 \%$ & 32730 & $49 \%$ & 67052 & $100 \%$ \\
\hline 1889 & 18489 & $91 \%$ & 698 & $3 \%$ & 1117 & $6 \%$ & 20304 & $100 \%$ \\
\hline 1890 & 18726 & $77 \%$ & 2737 & $11 \%$ & 2850 & $12 \%$ & 24313 & $100 \%$ \\
\hline 1891 & 5999 & $12 \%$ & 40150 & $80 \%$ & 4060 & $8 \%$ & 50209 & $100 \%$ \\
\hline 1892 & 6336 & $76 \%$ & 1909 & $23 \%$ & 101 & $1 \%$ & 8346 & $100 \%$ \\
\hline 1893 & 3195 & $5 \%$ & 64740 & $95 \%$ & 59 & $0 \%$ & 67994 & $100 \%$ \\
\hline 1894 & 11870 & $87 \%$ & 1545 & $11 \%$ & 180 & $1 \%$ & 13595 & $100 \%$ \\
\hline 1895 & 2911 & $81 \%$ & 614 & $17 \%$ & 68 & $2 \%$ & 3593 & $100 \%$ \\
\hline 1896 & 7699 & $95 \%$ & 127 & $2 \%$ & 292 & $4 \%$ & 8118 & $100 \%$ \\
\hline 1897 & 4304 & $88 \%$ & 330 & $7 \%$ & 274 & $6 \%$ & 4908 & $100 \%$ \\
\hline 1898 & 23692 & $73 \%$ & 8125 & $25 \%$ & 807 & $2 \%$ & 32624 & $100 \%$ \\
\hline 1899 & 59483 & $79 \%$ & 11594 & $15 \%$ & 3952 & $5 \%$ & 75029 & $100 \%$ \\
\hline 1900 & 33963 & $86 \%$ & 3303 & $8 \%$ & 2409 & $6 \%$ & 39675 & $100 \%$ \\
\hline 1901 & 23768 & $89 \%$ & 1534 & $6 \%$ & 1281 & $5 \%$ & 26583 & $100 \%$ \\
\hline 1902 & 11065 & $69 \%$ & 2407 & $15 \%$ & 2608 & $16 \%$ & 16080 & $100 \%$ \\
\hline 1903 & 29046 & $80 \%$ & 5456 & $15 \%$ & 1623 & $4 \%$ & 36125 & $100 \%$ \\
\hline 1904 & 35208 & $74 \%$ & 9079 & $19 \%$ & 3519 & $7 \%$ & 47806 & $100 \%$ \\
\hline 1905 & 104430 & $82 \%$ & 17242 & $14 \%$ & 5492 & $4 \%$ & 127164 & $100 \%$ \\
\hline 1906 & 137274 & $88 \%$ & 13003 & $8 \%$ & 6562 & $4 \%$ & 156839 & $100 \%$ \\
\hline 1907 & 110589 & $83 \%$ & 19237 & $14 \%$ & 4140 & $3 \%$ & 133966 & $100 \%$ \\
\hline 1908 & 33057 & $76 \%$ & 6605 & $15 \%$ & 3770 & $9 \%$ & 43432 & $100 \%$ \\
\hline 1909 & 25472 & $68 \%$ & 8806 & $23 \%$ & 3401 & $9 \%$ & 37679 & $100 \%$ \\
\hline 1910 & 30080 & $61 \%$ & 10220 & $21 \%$ & 9304 & $19 \%$ & 49604 & $100 \%$ \\
\hline 1911 & 25523 & $64 \%$ & 5071 & $13 \%$ & 9422 & $24 \%$ & 40016 & $100 \%$ \\
\hline 1912 & 35021 & $56 \%$ & 21372 & $34 \%$ & 6354 & $10 \%$ & 62747 & $100 \%$ \\
\hline \multirow[t]{2}{*}{1913} & 39057 & $58 \%$ & 17459 & $26 \%$ & 10964 & $16 \%$ & 67480 & $100 \%$ \\
\hline & 1074408 & $69 \%$ & 331891 & $21 \%$ & 154714 & $10 \%$ & 1561013 & $100 \%$ \\
\hline
\end{tabular}

\footnotetext{
Source: see text
} 


\begin{tabular}{|c|c|c|c|}
\hline & Nominal K & Paid up K & $\%$ \\
\hline 1883 & 135835 & 95561 & $70 \%$ \\
\hline 1884 & 87014 & 50753 & $58 \%$ \\
\hline 1885 & 228663 & 92721 & $41 \%$ \\
\hline 1886 & 54396 & 24201 & $44 \%$ \\
\hline 1887 & 75826 & 36496 & $48 \%$ \\
\hline 1888 & 79007 & 67052 & $85 \%$ \\
\hline 1889 & 53125 & 20304 & $38 \%$ \\
\hline 1890 & 34258 & 24313 & $71 \%$ \\
\hline 1891 & 115361 & 50209 & $44 \%$ \\
\hline 1892 & 15241 & 8346 & $55 \%$ \\
\hline 1893 & 223084 & 67994 & $30 \%$ \\
\hline 1894 & 18385 & 13595 & $74 \%$ \\
\hline 1895 & 11328 & 3593 & $32 \%$ \\
\hline 1896 & 22454 & 8118 & $36 \%$ \\
\hline 1897 & 18022 & 4908 & $27 \%$ \\
\hline 1898 & 74173 & 32624 & $44 \%$ \\
\hline 1899 & 246639 & 75029 & $30 \%$ \\
\hline 1900 & 111106 & 39675 & $36 \%$ \\
\hline 1901 & 49374 & 26583 & $54 \%$ \\
\hline 1902 & 44815 & 16080 & $36 \%$ \\
\hline 1903 & 70489 & 36125 & $51 \%$ \\
\hline 1904 & 112140 & 47806 & $43 \%$ \\
\hline 1905 & 349888 & 127164 & $36 \%$ \\
\hline 1906 & 448601 & 156839 & $35 \%$ \\
\hline 1907 & 343140 & 133966 & $39 \%$ \\
\hline 1908 & 110728 & 43432 & $39 \%$ \\
\hline 1909 & 93871 & 37679 & $40 \%$ \\
\hline 1910 & 115527 & 49604 & $43 \%$ \\
\hline 1911 & 79899 & 40016 & $50 \%$ \\
\hline 1912 & 104054 & 62747 & $60 \%$ \\
\hline 1913 & 118038 & 67480 & $57 \%$ \\
\hline
\end{tabular}

Source: see text 
Table 15: The JSC global dynamics 1883-1913

\begin{tabular}{|c|c|c|c|c|}
\hline & birts & deaths & difference & balance \\
\hline 1882 & & & & 747 \\
\hline 1883 & 63 & 11 & 52 & 799 \\
\hline 84 & 49 & 14 & 35 & 834 \\
\hline 85 & 81 & 15 & 66 & 900 \\
\hline 86 & 52 & 17 & 35 & 935 \\
\hline 87 & 73 & 18 & 55 & 990 \\
\hline 88 & 51 & 10 & 41 & 1031 \\
\hline 89 & 55 & 24 & 31 & 1062 \\
\hline 1890 & 37 & 19 & 18 & 1080 \\
\hline 91 & 35 & 28 & 7 & 1087 \\
\hline 92 & 31 & 27 & 4 & 1091 \\
\hline 1893 & 26 & 30 & -4 & 1087 \\
\hline 94 & 27 & 18 & 9 & 1096 \\
\hline 95 & 23 & 17 & 6 & 1102 \\
\hline 96 & 34 & 14 & 20 & 1122 \\
\hline 97 & 35 & 7 & 28 & 1150 \\
\hline 98 & 56 & 17 & 39 & 1189 \\
\hline 99 & 136 & 23 & 113 & 1302 \\
\hline 1900 & 101 & 13 & 88 & 1390 \\
\hline 1 & 80 & 25 & 55 & 1445 \\
\hline 2 & 74 & 21 & 53 & 1498 \\
\hline 1903 & 98 & 26 & 72 & 1570 \\
\hline 4 & 127 & 40 & 87 & 1657 \\
\hline 5 & 315 & 39 & 276 & 1933 \\
\hline 6 & 522 & 58 & 464 & 2397 \\
\hline 7 & 594 & 56 & 538 & 2935 \\
\hline 8 & 310 & 108 & 202 & 3137 \\
\hline 9 & 276 & 81 & 195 & 3332 \\
\hline 10 & 240 & 85 & 155 & 3487 \\
\hline 11 & 227 & 169 & 58 & 3545 \\
\hline 12 & 235 & 116 & 119 & 3664 \\
\hline 1913 & 223 & 114 & 109 & 3773 \\
\hline
\end{tabular}

Source: see text 
Fig. 1. Number of companies by sectors, 1876

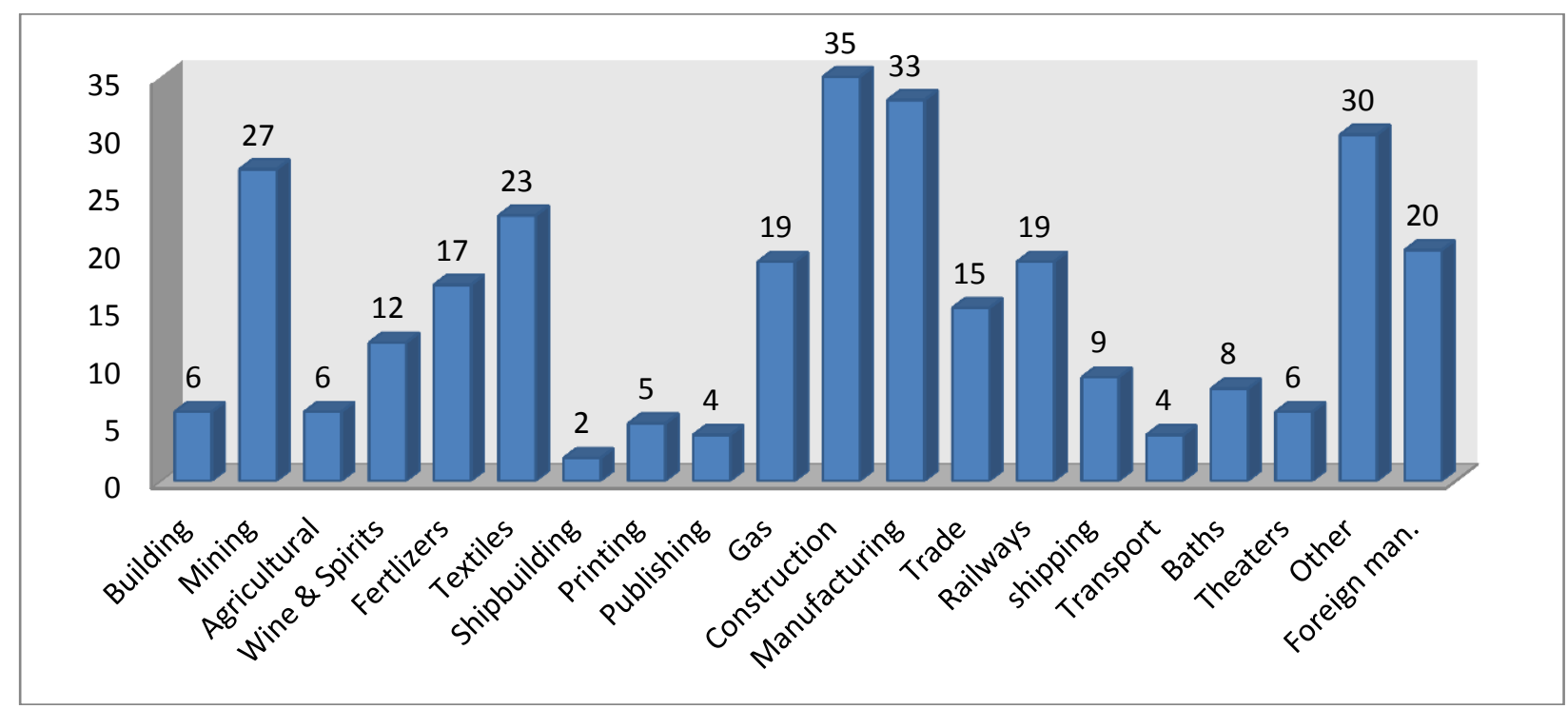

Fig. 2. Number of companies by sectors and regions, 1876
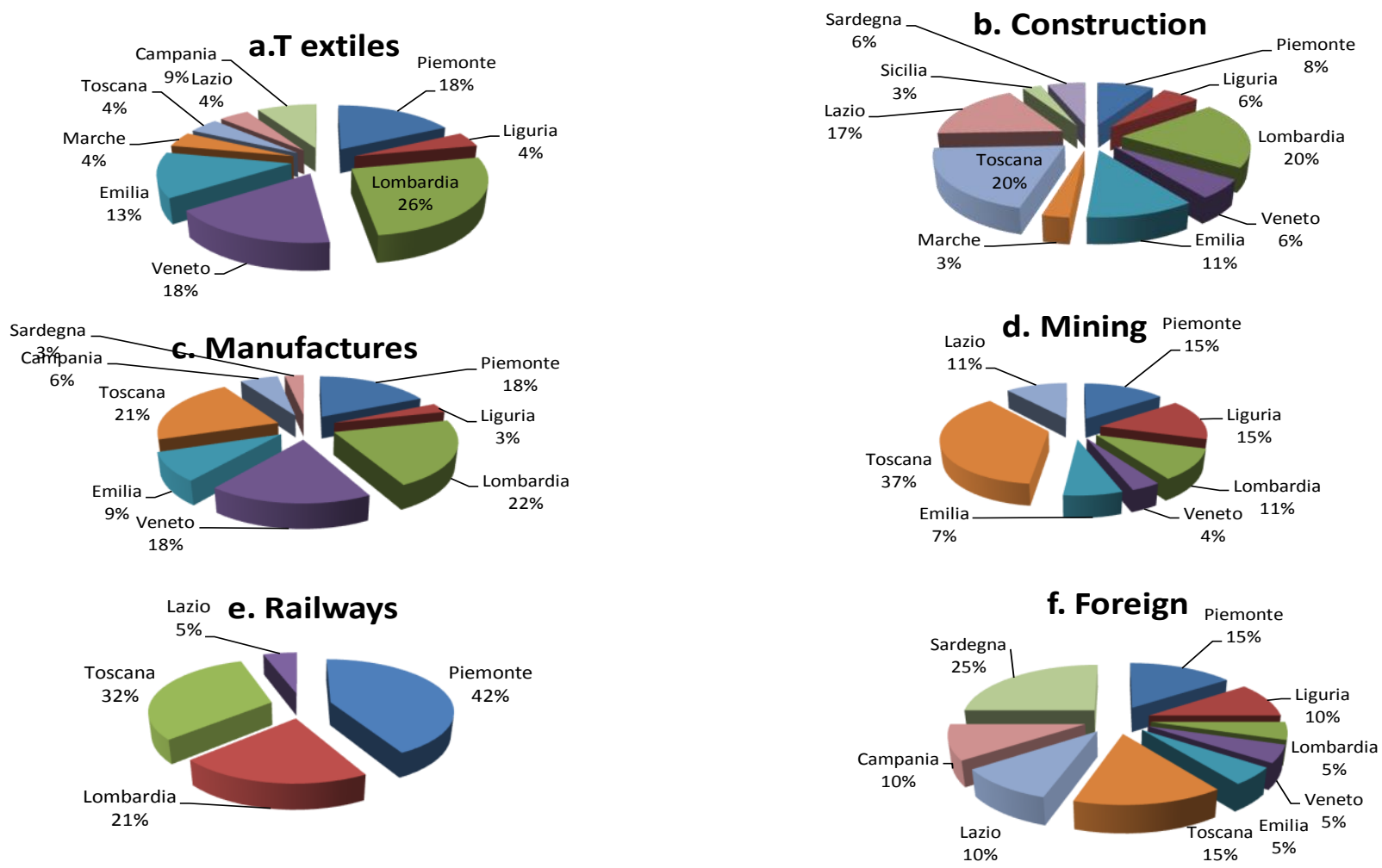
Fig.3. MAIC vs. Assonime data

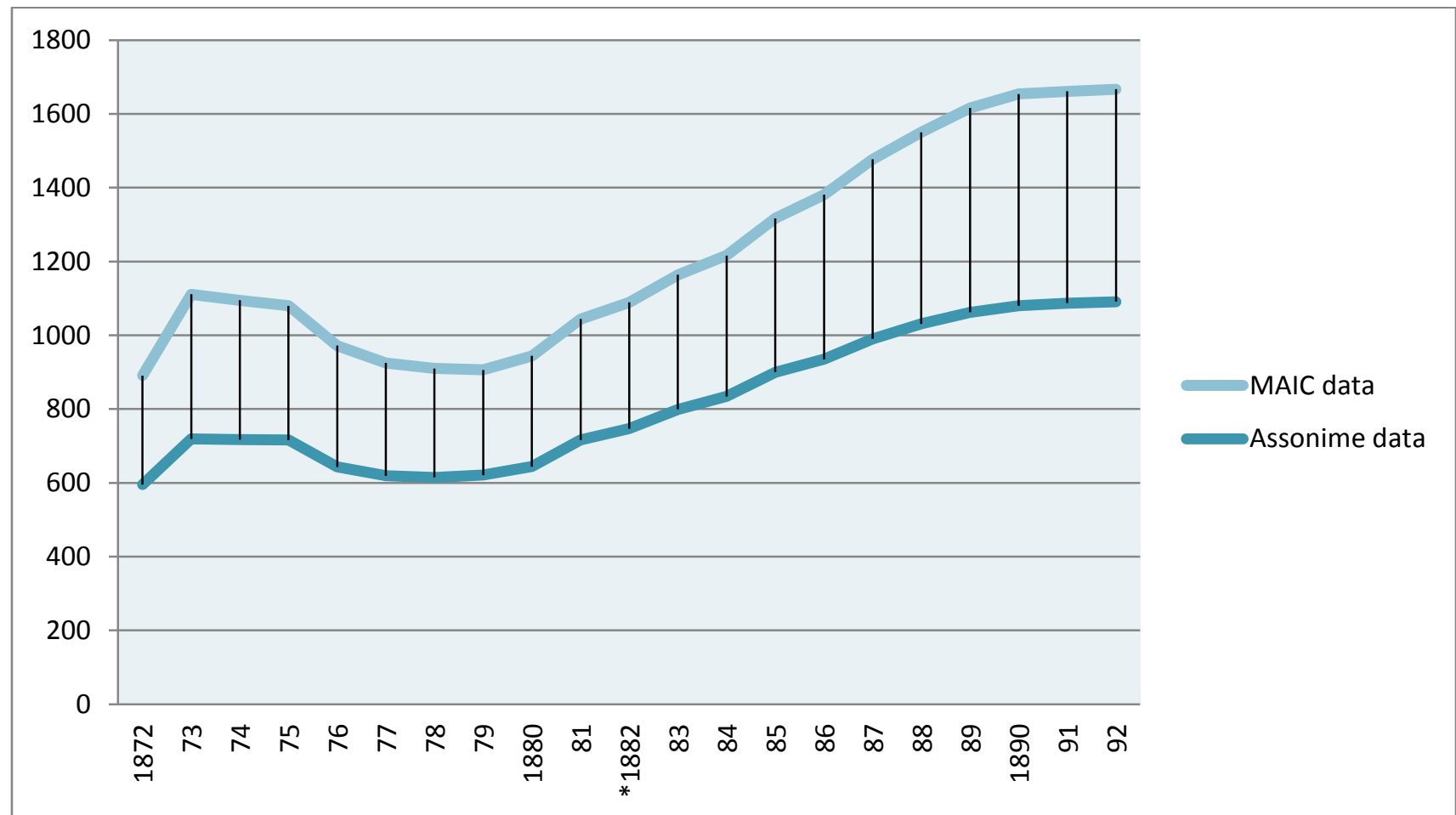

Fig.4 Sector frequencies by areas

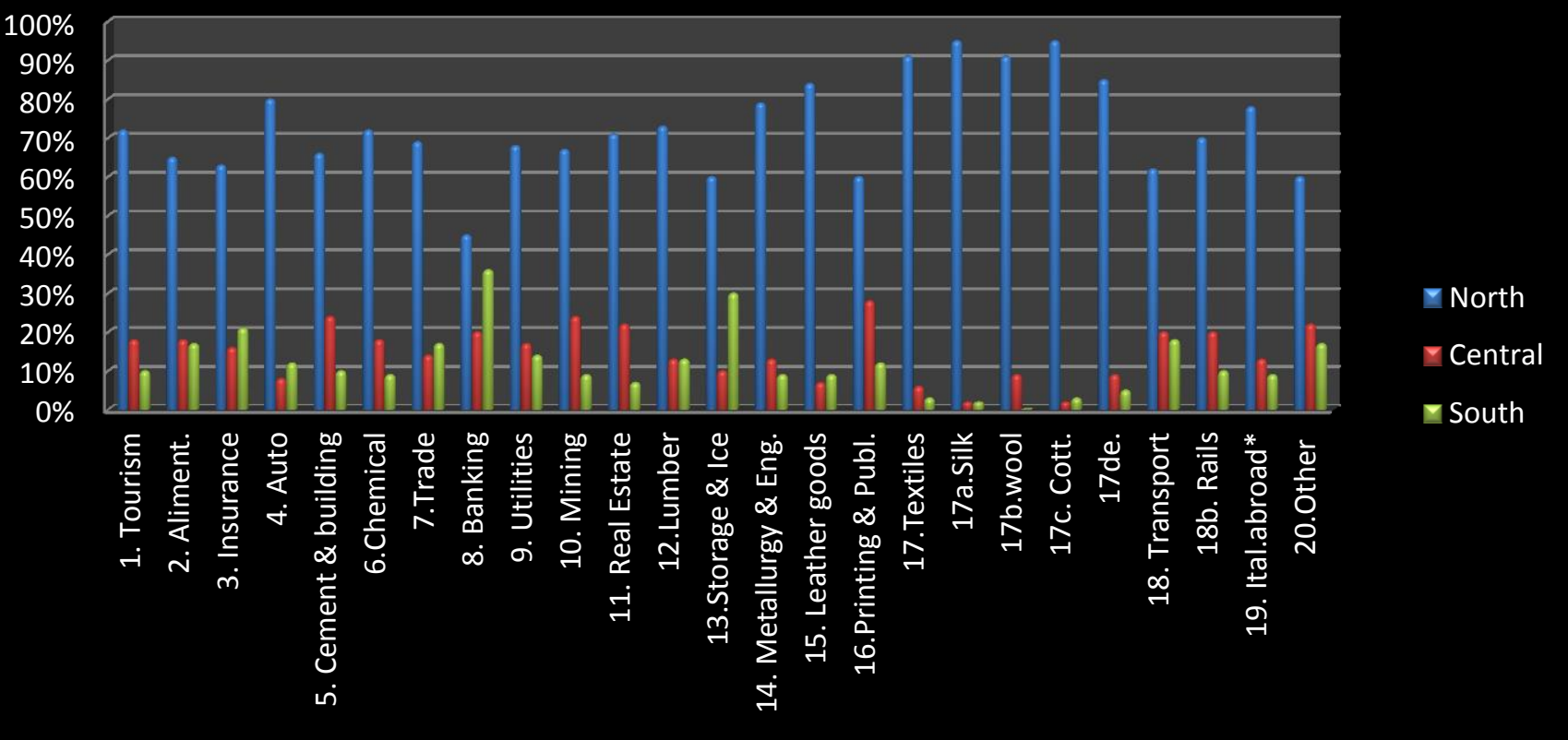




\section{Fig. 5 -The JSC births, \# (1883-1913)}

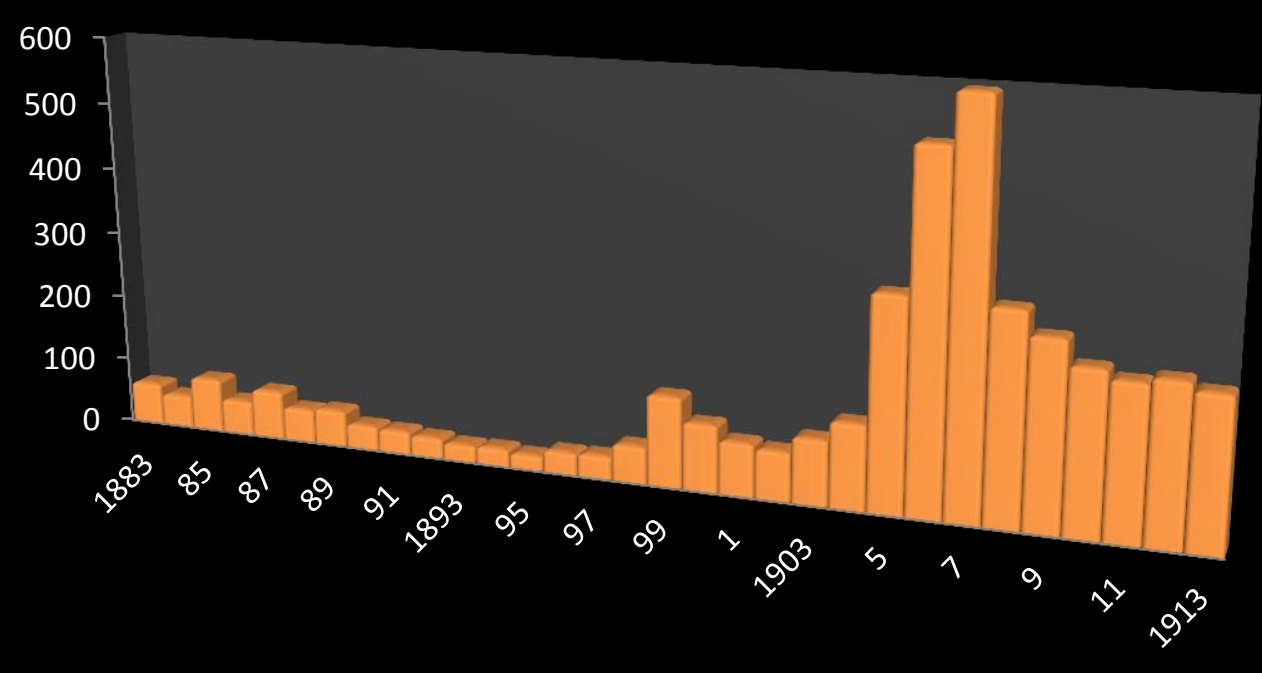

Fig. 6 - JSC yearly constitutions by macroarea

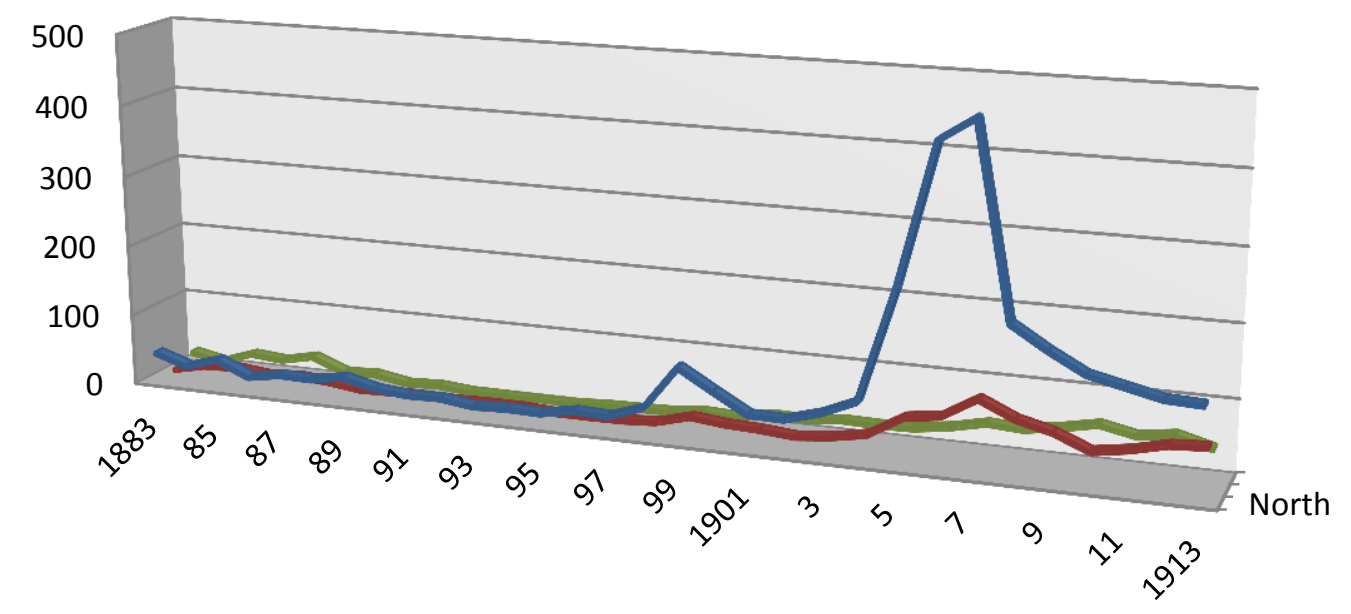




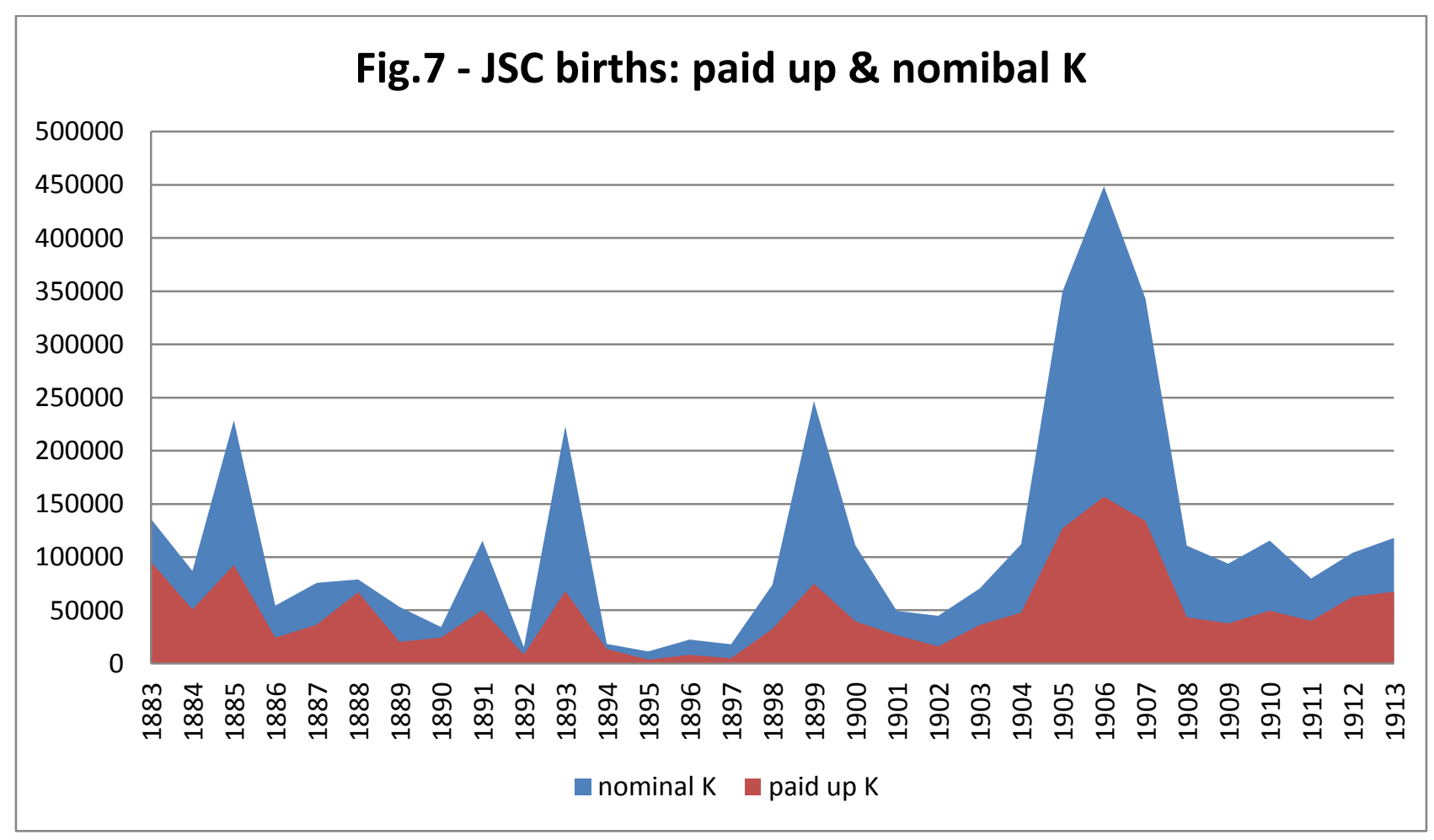

Fig. 8 JSC nominal K shares by area

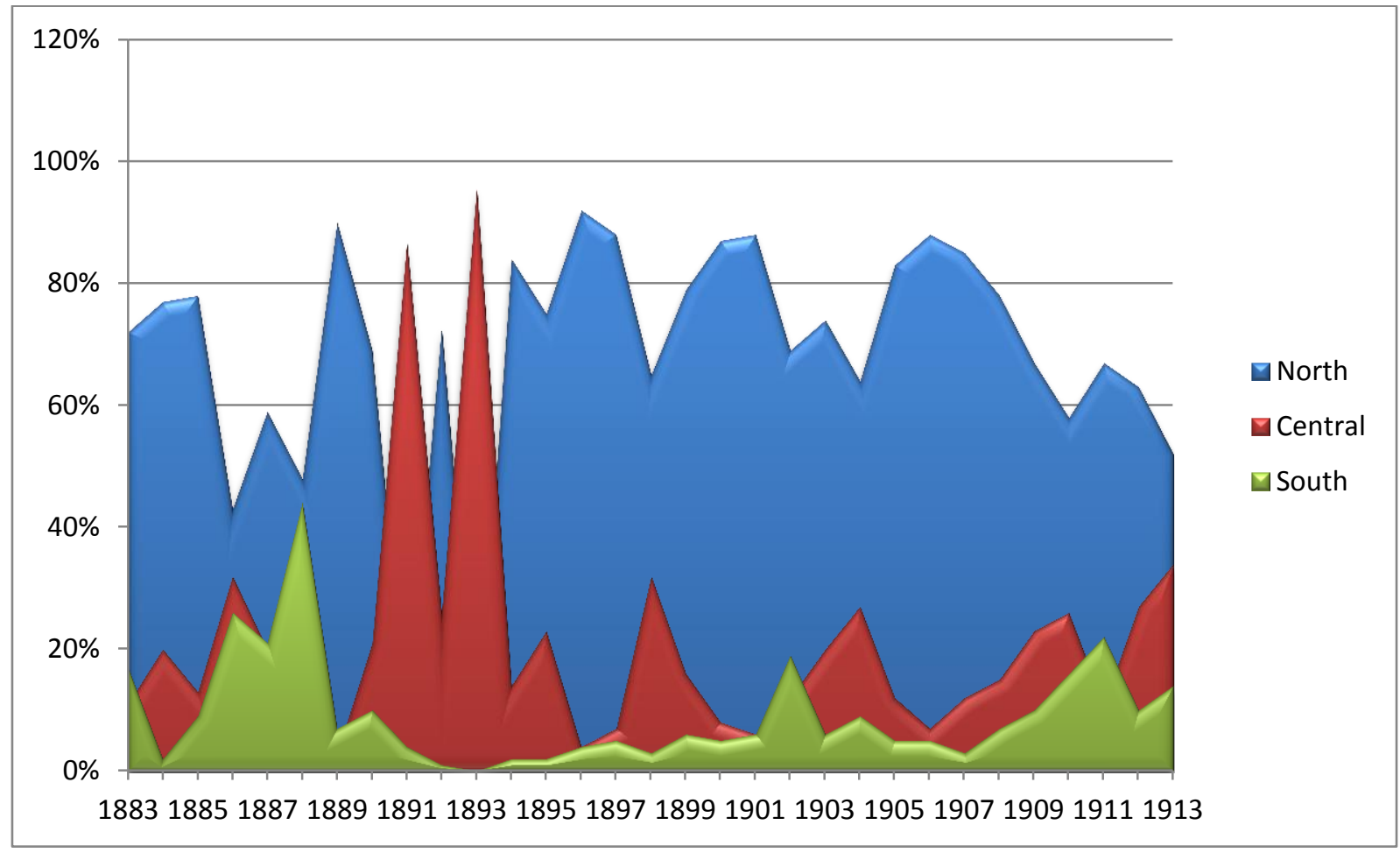


Fig. 9 J-SC shares by area

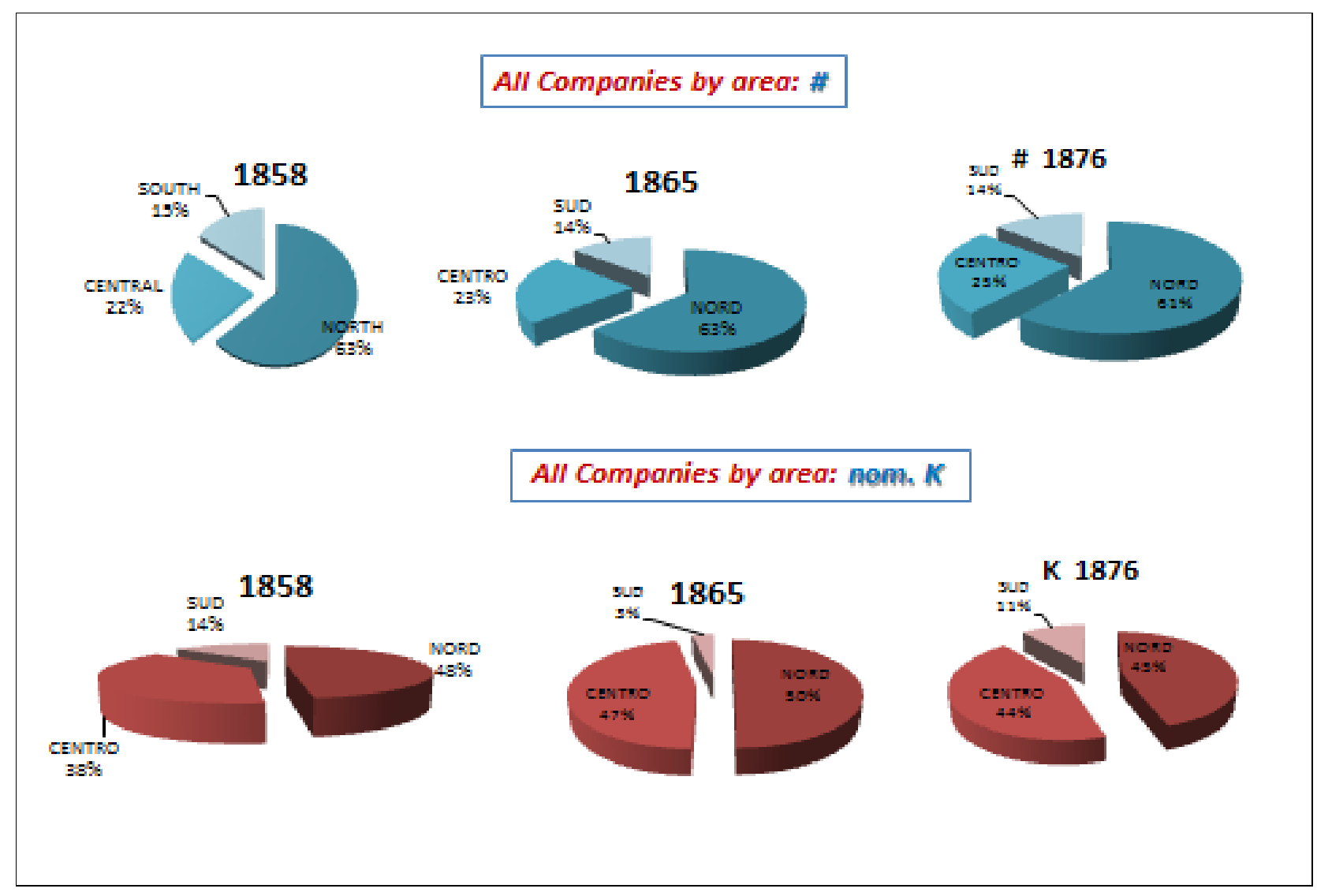

